\title{
Stem cell therapy for COVID-19 pneumonia
}

\author{
Maziar Malekzadeh Kebria ${ }^{1,2}$, Peiman Brouki Milan ${ }^{1,2^{*}}$, Noshad Peyravian ${ }^{1,2}$, Jafar Kiani ${ }^{3,4}$, Soheil Khatibi ${ }^{5}$ and \\ Masoud Mozafari ${ }^{*}$ (1)
}

\begin{abstract}
Severe Acute Respiratory Syndrome Coronavirus 2 (SARS-CoV-2) virus is a highly contagious microorganism, and despite substantial investigation, no progress has been achieved in treating post-COVID complications. However, the virus has made various mutations and has spread around the world. Researchers have tried different treatments to reduce the side effects of the COVID-19 symptoms. One of the most common and effective treatments now used is steroid therapy to reduce the complications of this disease. Long-term steroid therapy for chronic inflammation following COVID-19 is harmful and increases the risk of secondary infection, and effective treatment remains challenging owing to fibrosis and severe inflammation and infection. Sometimes our immune system can severely damage ourselves in disease. In the past, many researchers have conducted various studies on the immunomodulatory properties of stem cells. This property of stem cells led them to modulate the immune system of autoimmune diseases like diabetes, multiple sclerosis, and Parkinson's. Because of their immunomodulatory properties, stem cell-based therapy employing mesenchymal or hematopoietic stem cells may be a viable alternative treatment option in some patients. By priming the immune system and providing cytokines, chemokines, and growth factors, stem cells can be employed to build a long-term regenerative and protective response. This review addresses the latest trends and rapid progress in stem cell treatment for Acute Respiratory Distress Syndrome (ARDS) following COVID-19.
\end{abstract}

Keywords: COVID-19, Coronavirus, Stem cells, Acute respiratory distress syndrome, Tissue regeneration

\section{Introduction}

The coronavirus disease 2019 (COVID-19) pandemic virus spread rapidly and led to death from pneumonia. At first, it was thought to be seasonal influenza, but after much research, it became clear that it was a new case. After laboratory research, the type of virus was quickly identified [1]. Coronavirus family member SARS-CoV-2 was the name given to the virus, which spreads via respiratory droplets and contact surfaces [2]. The average incubation period is 3 to 5 days but ranges from 2 to 14 days [3]. However, the World Health Organization (WHO) announced 1 to 11 days recently. Patients with a mild respiratory infection are usually diagnosed with fever and

*Correspondence: brouki.p@iums.ac.ir; mozafari.masoud@gmail.com; m.mozafari@utoronto.ca

${ }^{2}$ Department of Tissue Engineering and Regenerative Medicine, Faculty of Advanced Technologies in Medicine, Iran University of Medical Sciences, Tehran, Iran

Full list of author information is available at the end of the article Masoud Mozafari, PhD; Currently at: Lunenfeld-Tanenbaum Research Institute, Mount Sinai Hospital, University of Toronto, Toronto, ON, Canada. cough, which are the most frequent signs of illness [4]. Among patients, only $14 \%$ had acute respiratory symptoms or ARDS [5]. However, the virus has spread around the world and has shown significant mortality. Various drugs are being tested to treat or control this disease. For example, Antiviral drugs, including redeliver and lopinavir-ritonavir, are under investigation, but the effects need further study [6]. Recently, countries have been using the hydroxychloroquine drug. It is used to treat malaria. Although this drug has shown appropriate cure effects, the use of these drugs in the treatment protocol needs to be more investigated. In addition to using these drugs, Chinese researchers have suggested using mesenchymal stem cells (MSCs) [7]. Due to their capacity to self-renew and specialize in functional cell types, mesenchymal stem cells (MSCs) have become an important source of cells for cell-based therapies [8-10]. Studies have recently reported that MSCs modulate the immune system. Researchers also show that inflammatory storms

\section{Springer}

(c) The Author(s) 2022. Open Access This article is licensed under a Creative Commons Attribution 4.0 International License, which permits use, sharing, adaptation, distribution and reproduction in any medium or format, as long as you give appropriate credit to the original author(s) and the source, provide a link to the Creative Commons licence, and indicate if changes were made. The images or other third party material in this article are included in the article's Creative Commons licence, unless indicated otherwise in a credit line to the material. If material is not included in the article's Creative Commons licence and your intended use is not permitted by statutory regulation or exceeds the permitted use, you will need to obtain permission directly from the copyright holder. To view a copy of this licence, visit http://creativecommons.org/licenses/by/4.0/. 
caused by the virus in the lungs may reason for severe pathogenesis $[8,11,12]$. Therefore, MSCs with their modulatory and anti-inflammatory properties, especially interleukin inhibition, can play an essential role in reducing the effects of COVID-19 in the lungs. We focused on the biochemical and clinical effects of mesenchymal cells on COVID-19 in this review research.

\section{The emergence of COVID-19}

For convenience, the virus was briefly called the SARSCOV-2 virus, and the $\mathrm{WHO}$ assigned the designation COVID-19 to the SARS-COV-2 virus-associated sickness $[13,14]$. All animals, including humans, can be infected by single-stranded RNA viruses [15-18]. They were initially identified in 1966 by Tyrell and Bynoe, who grew the viruses from individuals who had the flu. They were known as coronaviruses because of their spherical shape, which had a core-shell and a crown-like top (Fig. 1) [19]. There are four subfamilies of coronaviruses: alpha, beta, gamma, and delta. It is not unusual for gamma and delta-viruses to arise in pigs or birds. Of course, it is important to note that their genome size varies from 26 to $32 \mathrm{~KB}[1,20,21]$. The beta virus is the most dangerous and deadly among the groups that can infect humans, while the alpha subgroup has shown milder symptoms in mammals, especially humans. SARS-COV-2 is owned by the $B$ lineage of the beta-coronaviruses $[4,20]$. SARSCOV-2 may have been transferred to people by eating marine creatures [22]. However, the identification of the causative agent of this virus has not been entirely determined [23-25]. An important symptom that confirmed this disease was pneumonia [26-28]. Observations show that SARS-COV-2 average incubation time is 3 to 5 days. However, the incubation period of the virus has not been assessed definitely $[29,30]$.

In most cases, symptoms of the condition begin to emerge within a few days [31]. Cough, fever, exhaustion, and upper respiratory tract infections are among the most common symptoms of coronavirus. About 70\% of individuals will get dyspnea and other serious chest

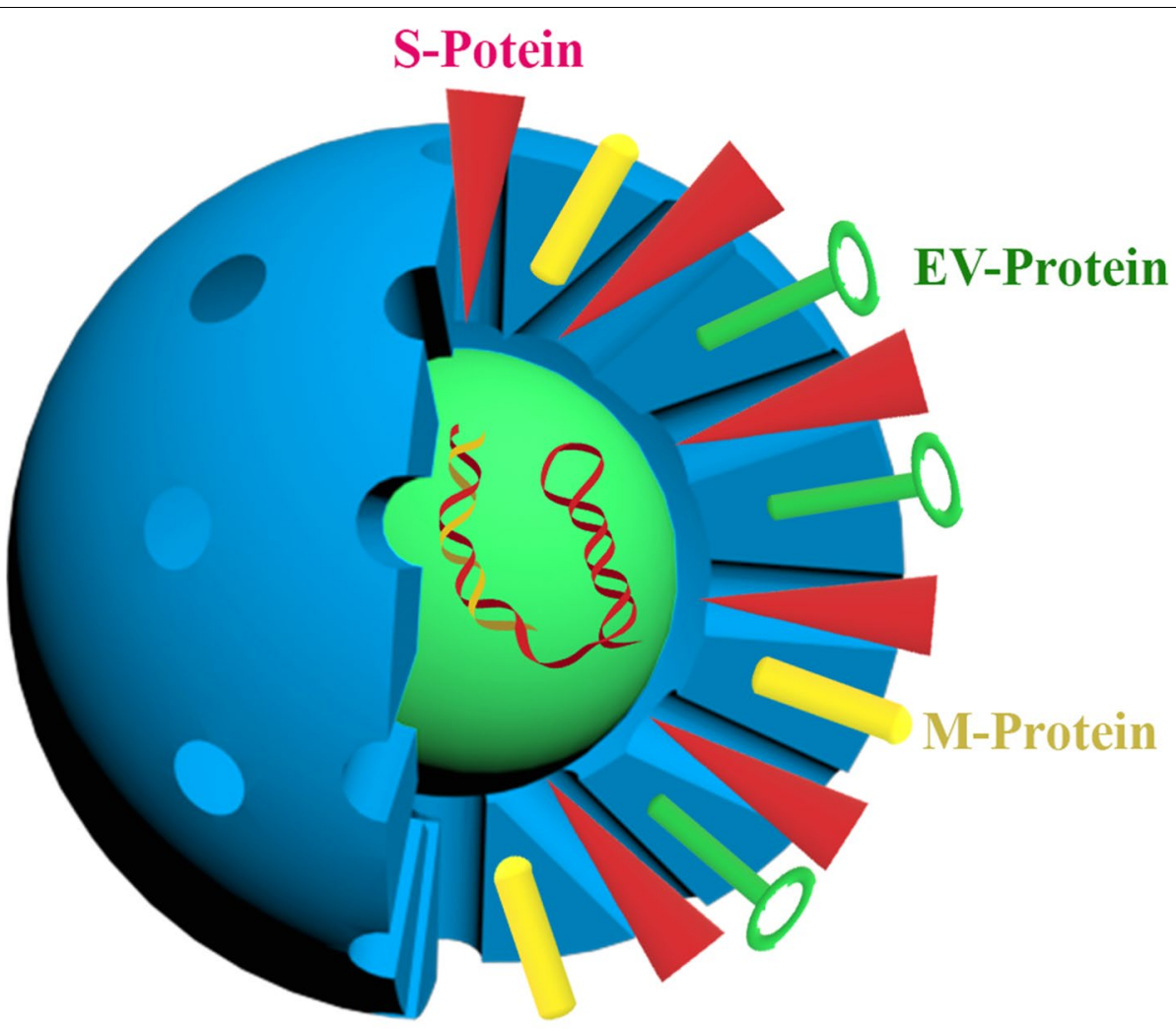

\section{Coronavirus structure}

Fig. 1 Coronavirus structure. In this structure, surface proteins (The spike protein (S-Protein), Envelope Protein (EV-Protein) and Membrane Protein (M-Protein), nucleotides and crowns of this virus are shown. The corona crown gives this type of virus a unique structure that distinguishes it from other viruses 
symptoms that communicate with pneumonia as a result of the infection [31,32]. Pneumonia usually begins two to three weeks after the onset of symptoms. Eminent indications of pneumonia consist of decreased oxygen saturation, and blood gas aberration changes evident through chest X-rays, maculate consolidation, alveolar exudation and interlobular contention [33, 34]. The pathophysiology of COVID-19 is similar to SARS-COV-2, which involves an intense inflammatory reaction in the airway resulting in severe lung damage. Accordingly, illness severity can be determined by the host's immunological response [35, 36]. A cytokine storm, which occurs when the immune system releases large amounts of cytokines in response to a viral infection or secondary infections, can result in $30 \%$ of fatal cases. Case numbers: COVID19 [37, 38]. In these cases, an uncontrolled inflammatory response causes damage to the liver, heart and kidneys. According to, many patients died due to the loss of function of these organs; however, most deaths are caused by lung damage $[39,40]$.

\section{Mesenchymal stem cells and therapeutic effects}

Embryonic stem cells and adult stem cells are the two primary types of stem cells, distinguished by their origin $[41,42]$. Adult stem cells such as mesenchymal stem cells are extremely important [43]. MSCs have the ability to transform into different cell lineage in vitro. Accessible sources and easy proliferation of these cells and autologous make them suitable candidates for cell therapy [44, 45]. A wide range of disorders has been treated with MSCs in the recent decade [46]. The clinical evidence showed that more than two thousand patients received MSCs as autologous and allogenic cells cultured in different diseases and syndromes $[47,48]$. By secreting tissue healing factors, they can change into all three germ layers and self-renew. Anti-inflammatory cytokines, vesicles and extracellular vesicles promote tissue and organ regeneration [49-51].

MSCs migrate toward damaged sites by secreting many factors and mechanisms, containing chemokine factors such as CXCR4 binds to its ligand CXCL12 caused trigger cell migration $[52,53]$. Tumour necrosis factor (TNFa), interleukin 10, and interferon-gamma (INFg) are all secreted by MSCs after being stimulated by inflammatory stimuli $[54,55]$. The connection of MSCs with a damaged microenvironment causes the release of complex factors in the proliferation and differentiation of local progenitor cells $[56,57]$.

MSCs have the right to control the growth and function of immune cells through their characteristics. For example, inhibiting the generation of antibodies by $\mathrm{B}$ cells, repressing NK cell proliferation, decreasing TNFand IL-12 production, inhibiting the differentiation of monocytes into dendritic cells, etc. . [58-60]. Antiinflammatory cytokines such as IL-10, on the other hand, increase the number of monocytes, which suggests that these cells can block dendritic cells from causing inflammation [61, 62]. As an additional advantage, MSCs modulate the innate immune system by inhibiting the activity of natural killer cells [63]. By lowering the expression of NKP44, NKG2D receptors and NKP30, MSCs focus on their inhibitory activity of NK cells [64, 65]. MSCs inhibit the production of hydrogen peroxide by activated neutrophils [66]. Therefore, these cells can reduce the intensity of inflammatory stimuli [67]. Immune system reactions can be lowered by using MSCs, according to these research $[68,69]$. It is critical to understand how MSCs affect the activity of $\mathrm{T}$ lymphocytes since these cells are regarded as the essential cells in the cellular immune system [70, 71]. It has been shown in several research investigations that monoclonal or allogeneic cells or particular antigens suppress the proliferation of $\mathrm{T}$ cells in the presence of MSCs [72]. These cells exert their inhibitory function on lymphocyte proliferation by stopping these cells in the $\mathrm{G}$ cell cycle. $\mathrm{CD} 4{ }^{+} \mathrm{T}$ lymphocytes [T helper, Th] are the main subcategories, each of which has phenotypic characteristics, and It is a self-contained function. Th1 and Th17 an inflammatory subtypes among these subcategories and guide inflammatory pathways [73-75]. The subcategories Th2 and Treg are also known as the population of suppressive cells or regulators of the immune system [76, 77].

From another perspective, MSCs have been caused slight immunogenic potential in vitro and in vivo due to their limited expression of MHC I molecules, the absence of MHC II statement and costimulatory molecules [78].

As a result of the immunomodulatory action of MSCs and their low MHC class I expression, allogeneic stem cell transplantation patients can avoid graft-versushost disease (GVHD) [79]. Numerous studies have been accomplished about various lineages of MSCs in diseases. For example, mesenchymal cells have been used to treat chronic heart injury, pancreatitis, diabetes, and various viral diseases [80]. Moreover, the role of translation MSC in cardiology, neurology and orthopaedics explain in a few reports, and it is one of the most promising therapeutic cells in these diseases and has also been widely used as a potential therapeutic target [47].

As mentioned, MSCs can be used in viral diseases. Various studies have been shown that damage to MSCs increases the entry of viruses and their pathogenicity. This cell type's function in HIV treatment, chronic HBV treatment, and influenza virus acute lung injury treatment (ALI) has been examined [81]. Taking the HIV-1 virus as an example, the virus is characterized by the total depletion of newly formed $\mathrm{CD} 4^{+} \mathrm{T}$ cells, resulting 
in severe immunodeficiency in the clinical environment. The most important function of MSCs is to aid in the restoration of the host immune system by decreasing the activation of $\mathrm{CD} 8^{+} \mathrm{T}$ cells and enhancing the effectiveness of $\mathrm{CD}^{+}{ }^{+} \mathrm{T}$ cell restitution. On the other hand, HBV is the most common pathogenesis in which 0.5 million people die from HBV-related liver disease or hepatocellular carcinoma worldwide each year [82]. Patients with end-stage liver disease who received human bone marrow-MSC had improved liver function. In acute lung injury (ALI) in influenza, the MSCs mechanism for modulation in the immune system has been used for treatment. Since these cells have been used to treat viral diseases (Fig. 2), researchers have found essential results in the treatment of COVID-19 due to its modulation effect [58].

\section{The effects of MSCs on acute respiratory distress syndrome [SARS-COV-2]}

An infectious agent causes respiratory illnesses. Similar respiratory symptoms can be found in a wide range of viruses, from the common cold to the most severe acute respiratory syndrome [83]. There is currently no authorized medicine or vaccination for COVID-19 illness. However medical organizations and scientists are working to develop a cure. Using emapticap, natalizumab, efalizumab, and convalescent plasma as immunomodulatory and immunoglobulin drugs in treating severe COVID-19 patients is effective [84-87].

SARS-inflammatory Cov-2's response is the primary method for destroying the virus, but this activity damages and dysfunctions the body's tissues. Viral entrance into tissue results in the release of pro-inflammatory molecules such as IL-1, IL-17, TNF-, and INF-. They can regenerate and regulate the immune system, which is useful for cell therapy. Mesenchymal stem cells (MSCs) come from many organs. It has been established that mesenchymal stem cells have considerable angiogenic and healing, anti-apoptotic, and immune-regulating capacities (Fig. 3). In addition, due to the low expression of MHC-I, MHC-II and excitatory molecules, they can

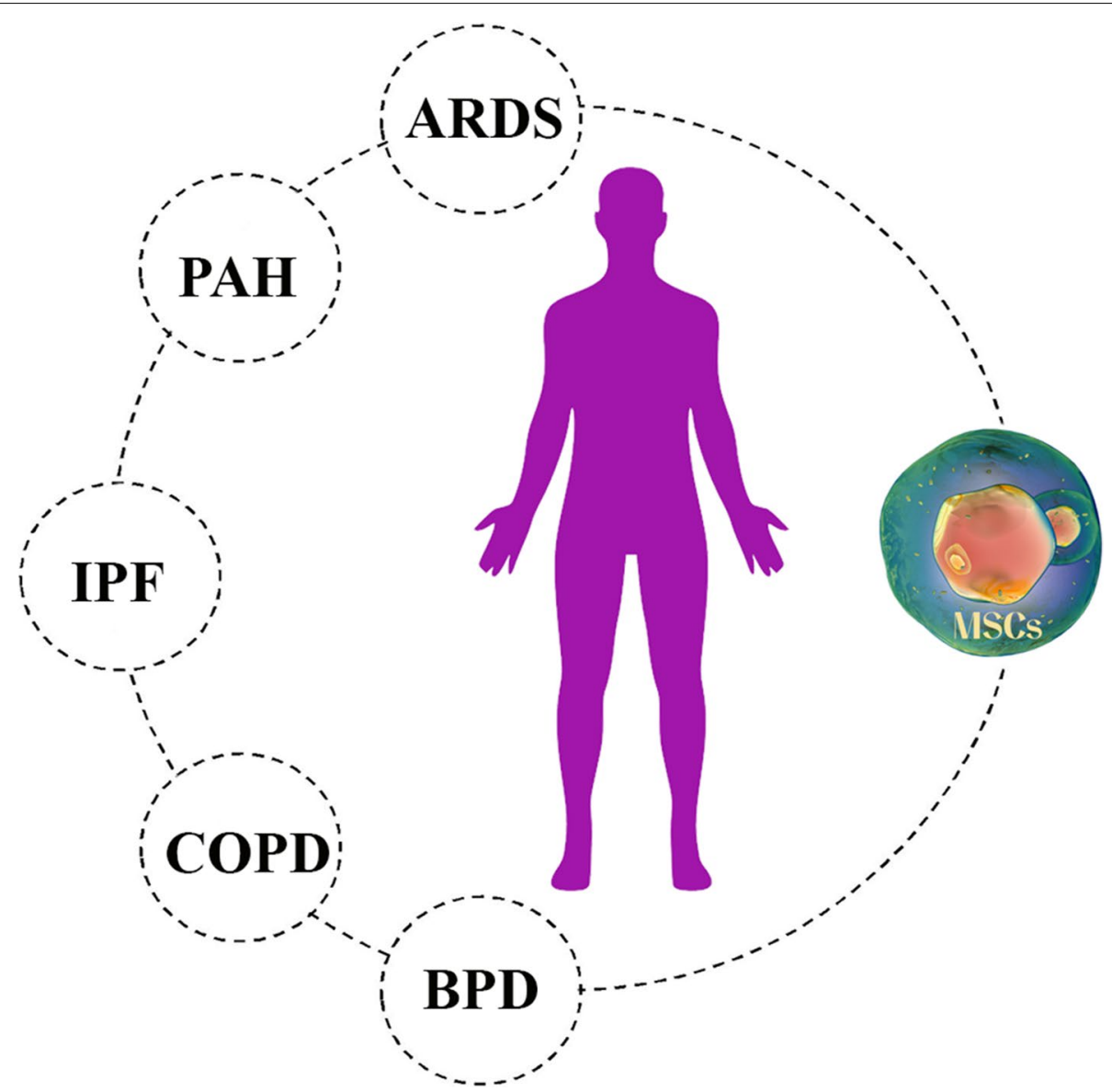

Fig. 2 The effect of Mesenchymal stem cells (MSCs) on a variety of lung diseases. These cells have the ability to regenerate damaged alveoli and fibrosis due to their regenerative and immunomodulatory properties. COPD (Chronic obstructive pulmonary disease), PAH (Pulmonary arterial hypertension), ARDS (Acute respiratory distress syndrome), BPD (Bronchopulmonary dysplasia) and IPF (Idiopathic pulmonary fibrosis) 


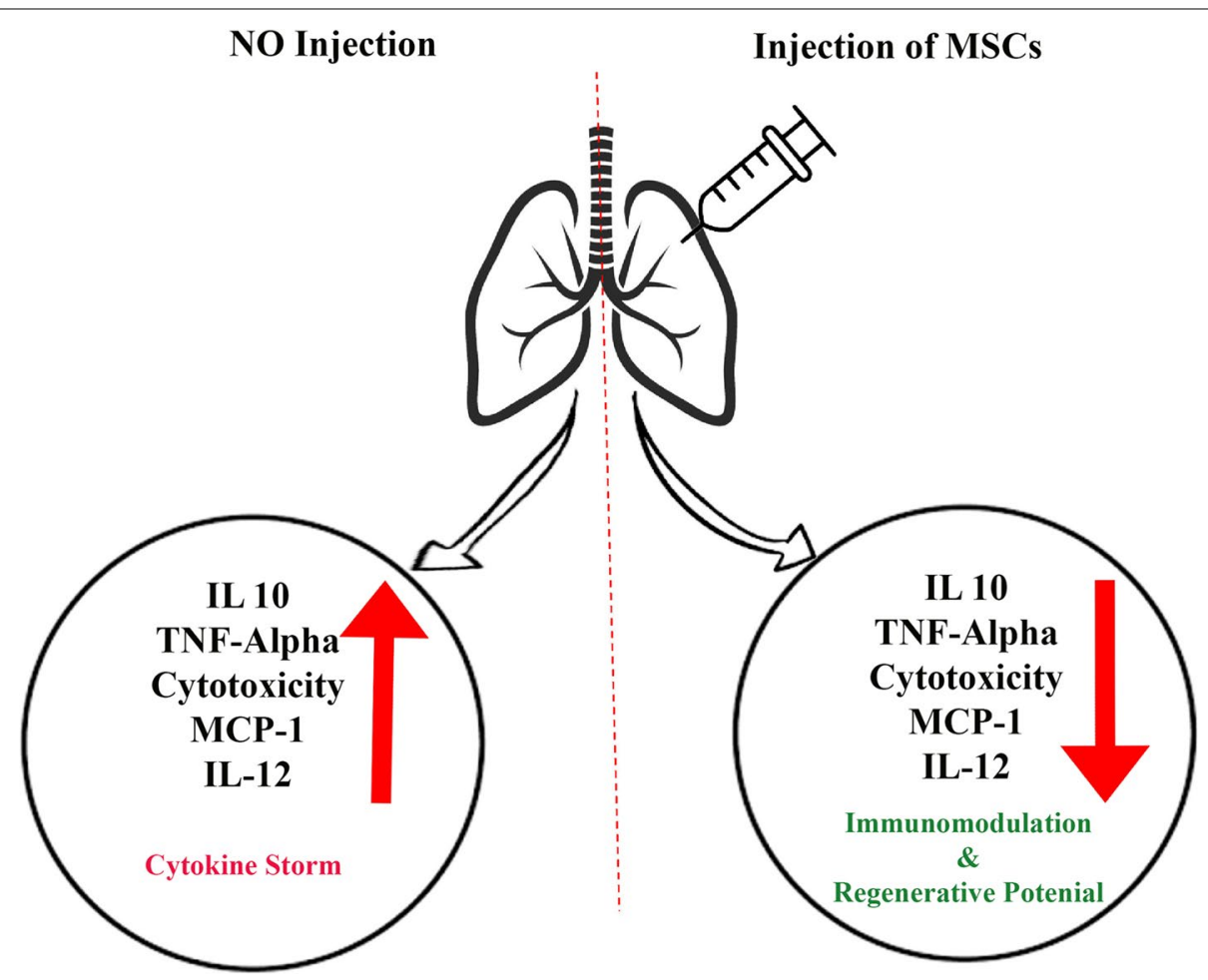

Fig. 3 Effects of Mesenchymal stem cells (MSCs) injection on the patient's lung. Injection of this cell reduces the secretion of interleukins 10, 12 and MCP-1. Reducing the secretion of these inflammatory factors prevents lung and respiratory diseases such as COVID-19

generally be characterized as evaporative and immune when used in allogeneic settings. Mesenchymal stem cells modulate the immune system by cell-paracrinedependent mechanisms, including releasing TNF, IL-10, indolamine 2,3-dioxygenase, adenosine, and extracellular vesicles. Additionally, these mechanisms result in decreased differentiation and activation of other immune cells. When it comes to treating inflammatory illnesses, mesenchymal stem cells are an excellent option. Considering inflammatory diseases, the most consistent data are related to mesenchymal stem cells in transplant therapy. When transplantation takes place, the immunomodulatory effects of mesenchymal cells are already prominent. Following an intravenous injection of cells, mesenchymal stem cell treatment is commonly used. Mesenchymal stem cells (MSCs) were shown to be swiftly struck in the lungs following intravenous injection, and damaged regions increased MSC migration, which is interesting. As a result of lung damage, angiotensin II synthesis in the capillaries increases, resulting in angiotensin II receptor interactions that stimulate MSC migration in-vivo. Anti-inflammatory cytokines and antimicrobial peptides are released by mesenchymal stem cells when they are stuck in the lungs, as described elsewhere in the body. Vaccines, antibodies, antivirals, and RNA-based medications and living therapies utilizing promising cell types like natural killer (NK) cells and stem cells have all been proposed as potential treatments [88, 89]. Therefore, the clinical experience chiefly comprised of antibacterial and antiviral drug treatments have been recognized to prohibit the ingress of these viruses in cell culture or animal models. Furthermore, antiviral drugs are the primary line treatment for COVID-19 induced pneumonia and can effectively obliterate the virus. Antiviral drugs cannot amendment damaged lung cells [10, 90]. Newly, stem cell therapy has become an excellent approved tool for treating viral lung damage. Because attempts to treat lung damage with a variety of drugs have not been successful, the use of cell therapy has been suggested. MSCs have a high ability to repair and regenerate. Due to these properties and modulating the immune system, researchers have considered these cells [91]. Plenty of clinical trials are done for this cell (Table 1).

MSC-based treatments also showed encouraging results in the experimental therapy of lung failure by reducing alveolar collapse, collagen buildup, and cell death in the tissue. In addition, several researchers have achieved results. Patients with induced acute respiratory distress syndrome were treated for the first time with MSCs produced from allogeneic menstrual blood. They observed improved lung function after using MSCs [92]. The three preferred antiviral mechanisms that 

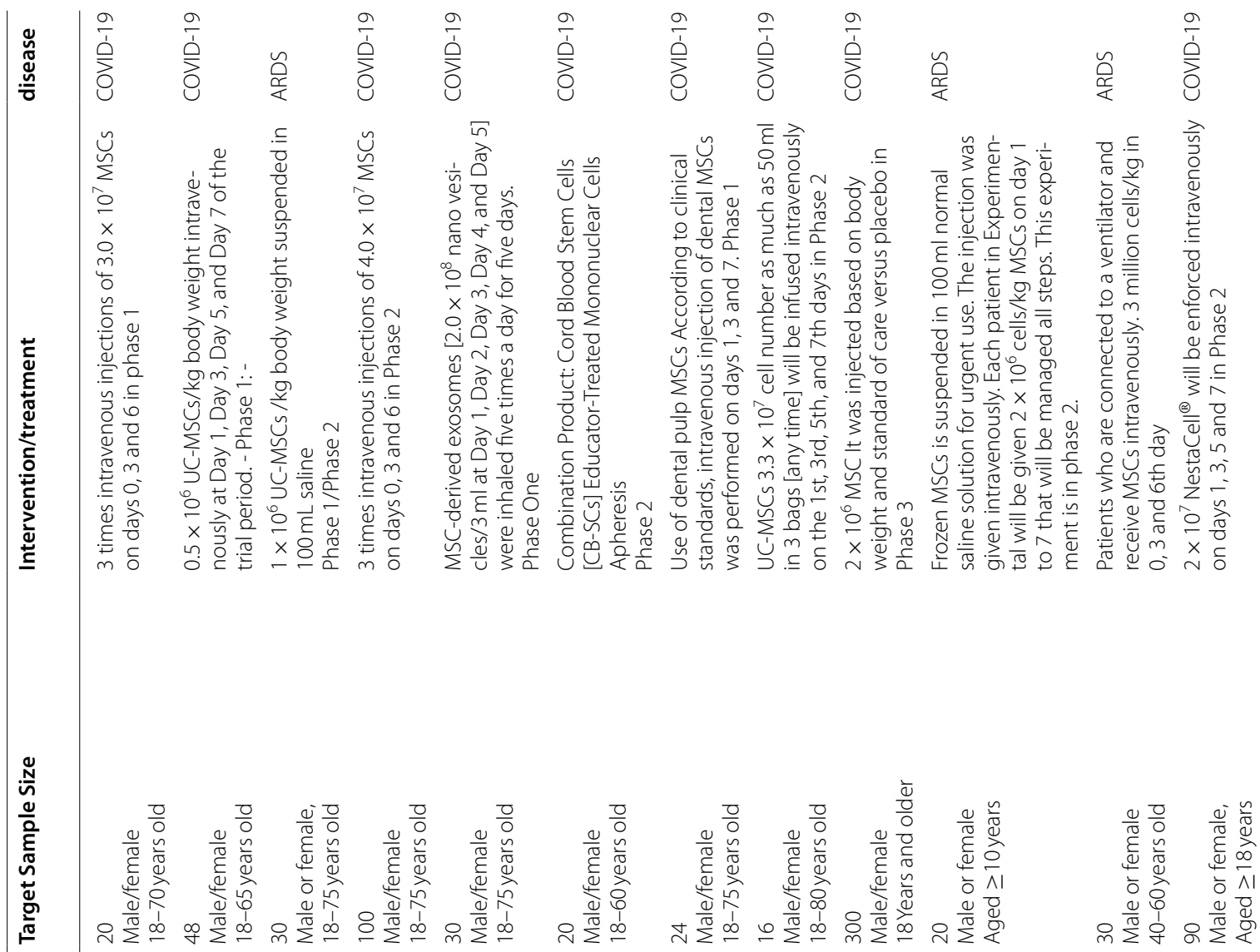

츙

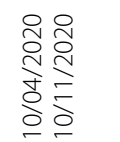

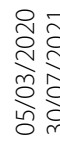

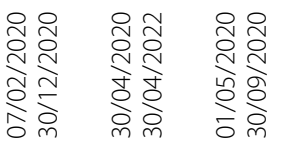

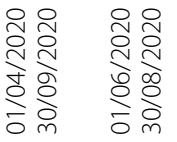




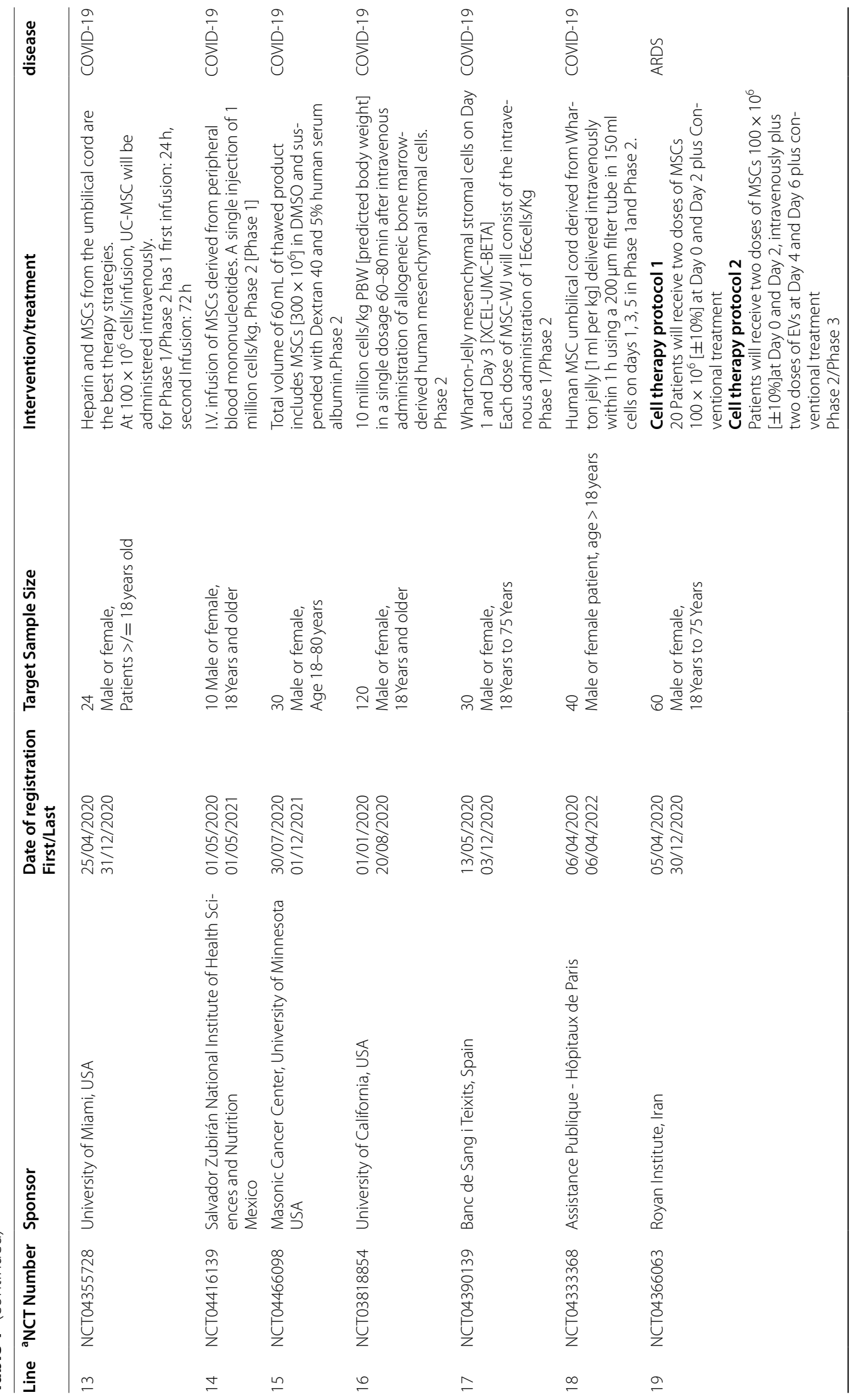




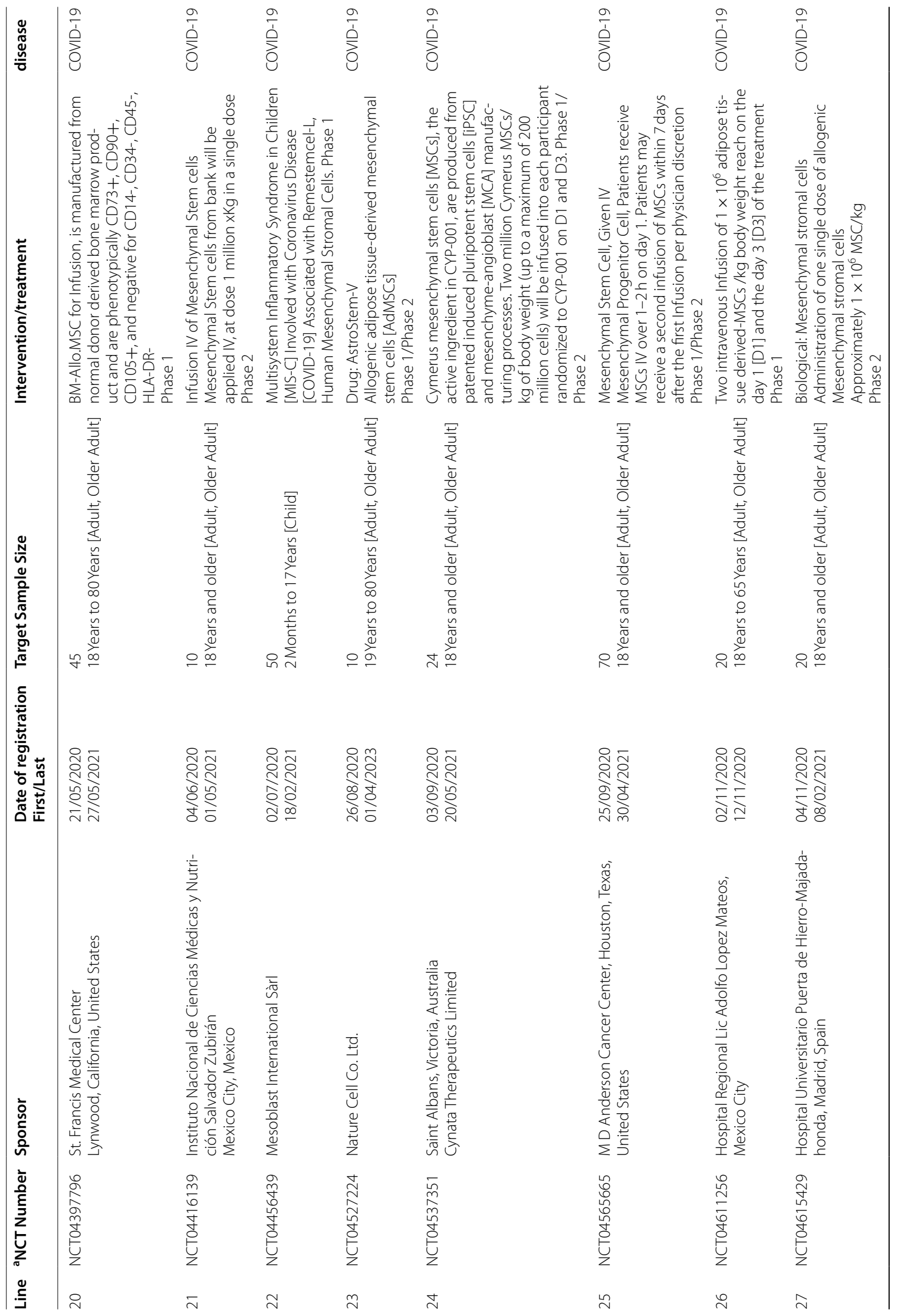




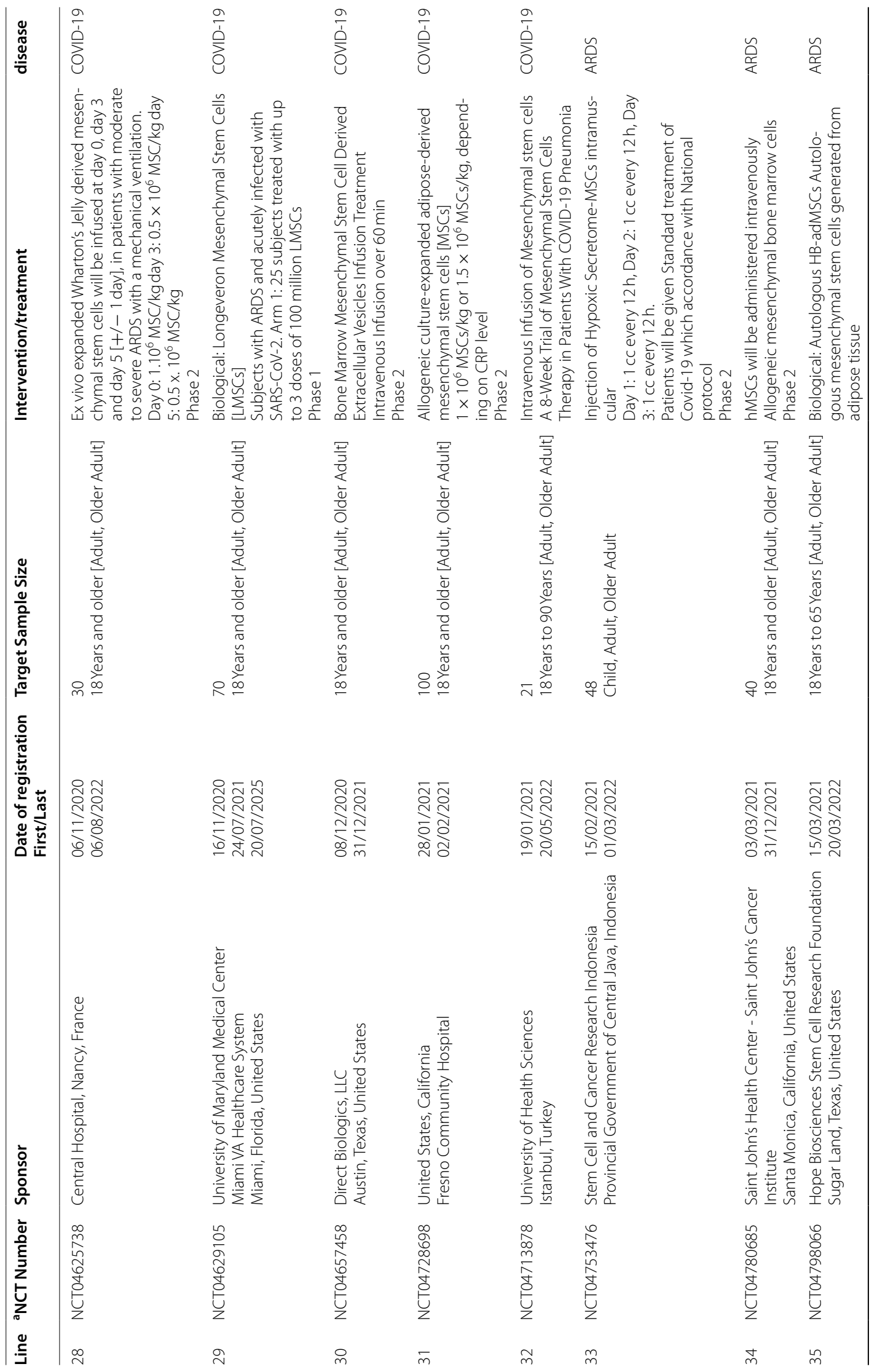




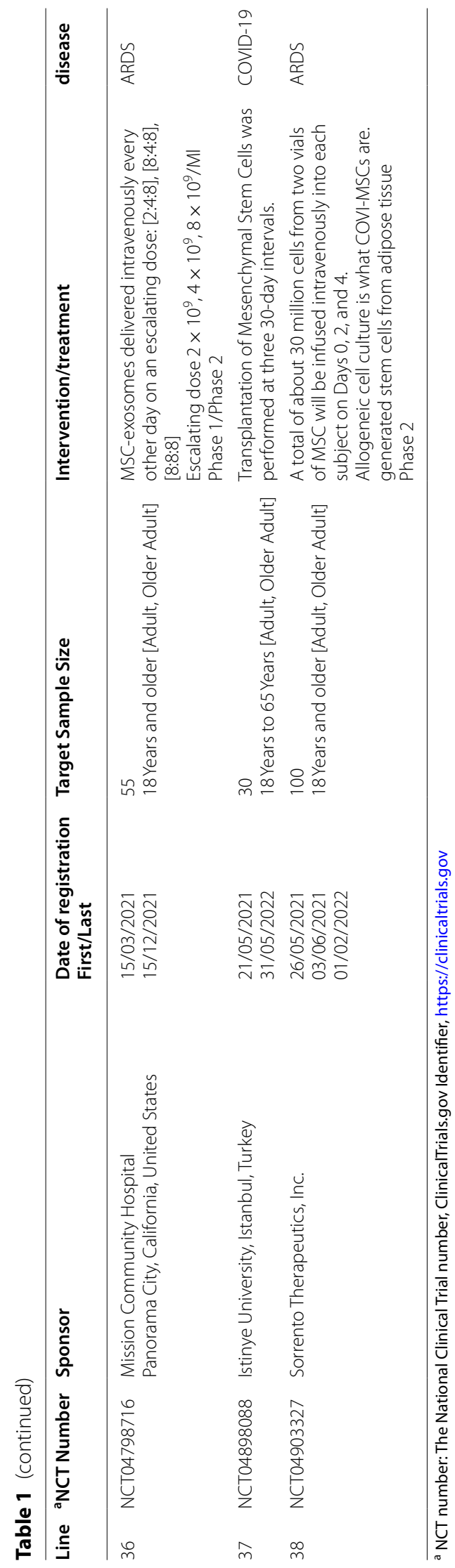


MSCs might exhibit in the context of a respiratory viral infection, such as COVID-19, include increased surface expressions of MSCs specific IFN-stimulated genes, secondary response to IFN, leading to the induction of MSC-stimulated genes that contribute to widespread viral resistance, and third modulation of the immune system. Aside from this, MSCs are ideal for treating SARSCOV-2 infection, which occurs when the immune and anti-inflammatory systems in the lungs get overwhelmed by cytokines (Fig. 4).

IFN-, an antiviral immune response, can activate MSCs and lead to the production of anti-inflammatory mediators, even if the mediators responsible for alleviating lung damage caused by the respiratory virus are still unclear [93-95]. Angiopoietin-1 and keratinocyte growth factors, released by MSCs, have been shown to play a role in regenerating alveolar-capillary barriers in acute respiratory syndrome. In addition, some literature has shown that the presence of a DAMP and PAMP mechanism causes lung inflammatory reactions. Due to their role in downstream cell signalling pathways, MSC activation is induced by Toll-like receptors (TLRs) triggered by viral RNA such as TLR3 in COVID-19 and viral nonmethylated CpG-DNA such as TLR9. Stem cell treatments and secretory extracellular vesicles (EVs) have been found to be potential new medicines for reducing inflammation and repairing damaged tissue. Lung injury caused by COVID-19. Particular inhibitory miRNAs in EVs explain as mediating the protective effects of MSCs in pre-clinical models of viral acute lung injuries [65, 96, 97]. With the advent of COVID-19, one of the best strategies for treating or controlling the disease is to use antiviral drugs, targeting virus replication $[98,99]$. These include favipiravir and remdesivir, which is an antiviral drug. However, because storm cytokines are found mainly in COVID-19, it is essential to consider drugs that inhibit the virus when replicating cytokine storms [100]. Because of this, MSC-Exos may be a suitable therapy for COVID-19. In some instances, using exosomes or secretions rather than mesenchymal stem cells themselves may be more effective and beneficial than traditional mesenchymal stem cell treatment [101]. With less toxicity and the ability to reach cells for more effective objectives through exosomes, exosomes can be extensively generated and prescribed [102]. In addition to its role in modulating the innate immune system, MSC-Exos can also be used as a drug delivery system. MSC-Exos can be modified in vivo to release exosomes that have the potential to modulate the immune system and can be cultured using different cytokines to show anti-inflammatory status [103]. Although MSC-Exos appear to be an appropriate therapeutic role for COVID-19, more clinical studies are needed to use them.
Additionally, it is critical to developing a strategy for preserving and isolating MSC-Exos for COVID-19 therapy. Furthermore, investigations are needed to understand COVID-19's underlying mechanisms better so that MSC-Exo therapy may be improved for treatment. Additionally, determining the optimal dosage, delivery technique, and treatment strategy for MSC-Exos is critical. As a result of their more outstanding research in these areas than MSC-Exos, MSCs are primarily selected in COVID-19 clinical studies [104, 105].

\section{Severe COVID-19 and MSC-based therapy treatment options}

COVID-19 has a strong association with advancing years. Men over the age of 75 who have a history of diabetes, hypertension, heart disease, chronic respiratory disease, cancer, or a history of surgery have the highest mortality rate [106-108]. The cellular immune system must be used to combat COVID-19 virus [109, 110]. Italy has the highest elderly population in Europe and the world's second-oldest population [111]. Italy also has one of the highest smoking rates, lung disease and ischemic heart disease [112]. Hence, the mortality rate in this country is higher compared to other countries [113]. However, young and healthy people can get the disease and die. The mortality rate from this virus is estimated at $4.3 \%$ [114-116]. Conventional treatments, such as hydroxychloroquine, are often not suitable and are not used in treatment. However, this drug is prescribed by some doctors. Recently, RamedSavier has been introduced as an antiviral drug [117]. Remdesivir is an adenosine analogue targeting viral RNA polymerase and inhibiting viral RNA synthesis [118]. Antiviral drug umifenovir, sold under the trade name Arbidol, is being studied and may be an alternative for treating the virus. COVID-19 [119-121]. Lopinavir/Ritonavir Neuraminidase, DNA inhibitors like Tenofovir Disoproxil or Lamivudine, and medicines like EK1 Peptide are alternatives to antiviral medications for COVID-19 therapy. Interferon recombinant has also been demonstrated to be effective [122-125]. Also, intravenous IVIG is prescribed for all ages. It can reduce inflammatory cytokines and increase effective antiinflammatory mediators [126] prescribed of thymosin $\alpha$ can restitute the immune system of these people [127]. Plasmotherapy by injecting plasma into people recovering from Covid-19 due to the presence of specific IgM, IgG and IgA antibodies against COVID-19 antigen markers can neutralize the virus in patients, clear it and prevent it from replicating. So it helps patients recover faster [128-130]. Since most viral infections reach their peak in the first week, plasma therapy is more effective early in the illness [131-133]. As ACE2 receptor expression in the human kidney is approximately 100 times greater 


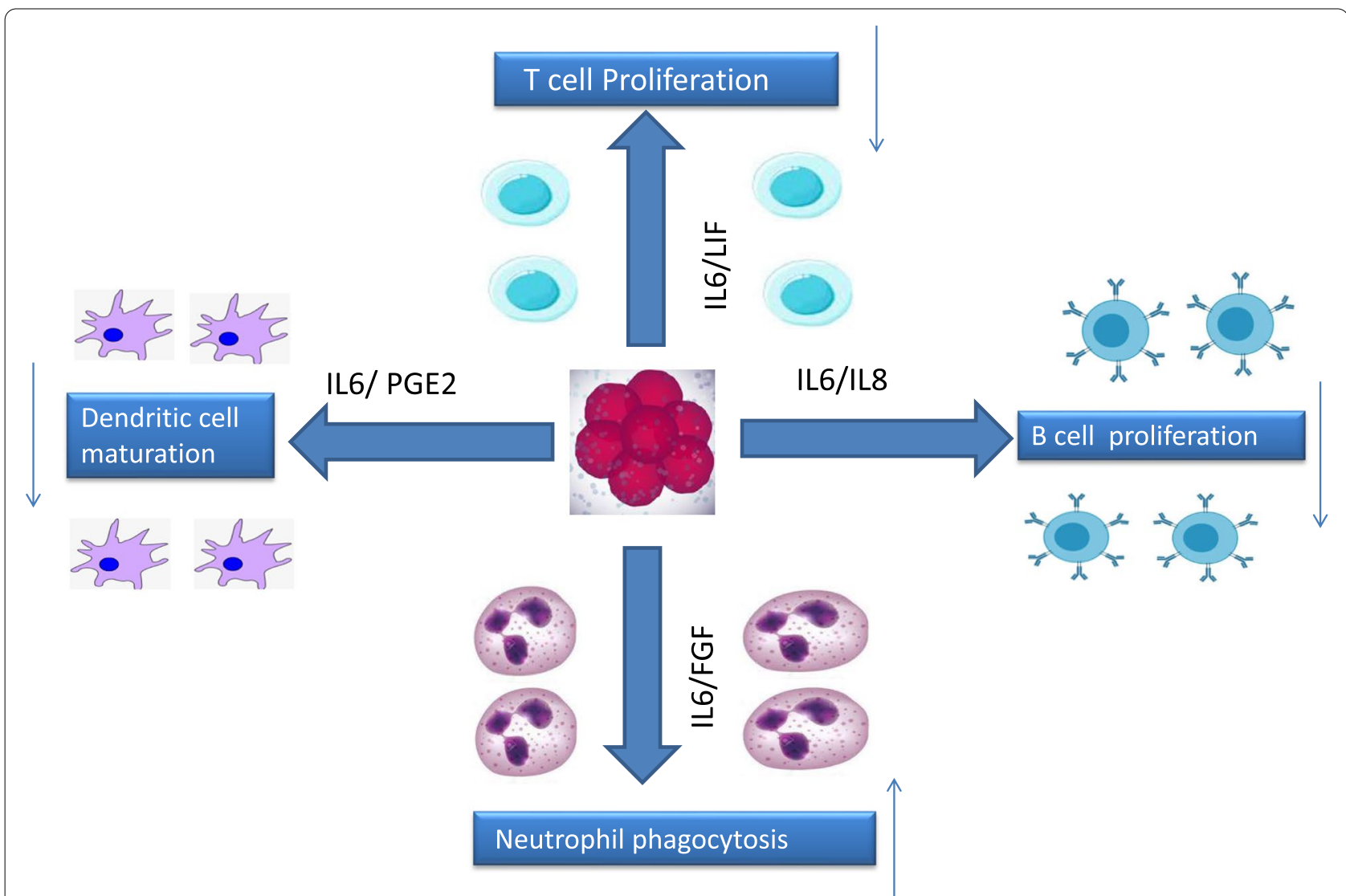

Fig. 4 Effect of Mesenchymal stem cells (MSCs) on dendritic cell, B cell, T cell and Neutrophil. Mesenchymal stem cells with the effect of interleukin 6,8, LIF and PGE2 reduce cell secretion and increase the activity of dendritic cells

than in the lung, the kidney has become a primary target for COVID-19 infections. Therefore, blood purification helps to improve kidney function by reducing the activity of the kidneys. Blood purification also prevents cytokine storms by eliminating inflammatory and destructive factors [134-139]. In addition, blood purification balances electrolytes and the blood buffering system, resulting in homeostasis and increased oxygen loading capacity by red blood cells [140-142]. A novel strategy for treating this condition involves the use of mesenchymal stem cells [143]. According to clinical studies, patients with a severe disease state respond correctly to effective adjuvant therapy, which improves health and reduces mortality [144]. Current regenerative drug-based adjuvant treatment, including recovery plasma injections and mesenchymal stem cell transplants, has been admitted into clinics or clinical studies $[145,146]$. The capacity of allogeneic mesenchymal stem cells and MSC-derived EVs to divide and proliferate may be proven as an effective adjuvant treatment with fast diffusion by intravenous injection of COVID-19. This therapy is now being evaluated and may become widely available soon $[147,148]$. The first MSC injection into human patients began in 1993. Since then, in the last 25 years, MSC injections have been recorded in about 1000 clinical trials and treated more than 10,000 patients [149-151]. MSC has the properties of reducing the inflammatory response and strong repair [152]. Previously, mesenchymal stem cells were clinically evaluated to treat disorders associated with host-to-host transplantation [153], viral-induced immunological deficiencies, and chronic infection with human immunodeficiency virus, hepatitis B virus, and influenza virus [154, 155]. It has been shown that mesenchymal stem cells are attracted to the inflammatory location [156]. Inflammation follows the secretion of cytokines and attaches to the endothelium [157]. To summarize, the immune control mechanism of the MSC involves modifying immune activity and inhibiting immune cells implicated in inflammation that reach the lungs' tissue [158-161]. These drugs also assist in the reduction of interferon IFN- production by natural killer cells (NK cells) and the alteration of the cytokine secretion profile by dendritic cells [162]. In various studies, mesenchymal stem cells in ALI and ARDS have been well described. MSCs 
perform their function by targeting infectious, inflammatory and endothelial agents. Mesenchymal stem cells have the ability to release KGF2, PGE2, IL-6, and IL-13 to aid in the process of phagocytosis [163-166]. In addition, lung injury from sources other than coronavirus has been the subject of several clinical research investigating the effect of mesenchymal stem cells [167]. Mesenchymal stem cells and their secreted secretions have immune, anti-inflammatory, anti-apoptotic functions (see Fig. 5) [99]. Recent studies have also shown anti-fibrotic properties in ALI and ARDS [168]. Macrophages' M1 to M2 transition is facilitated by PGE2 and IL10, whereas IDO enhances the lungs' antibacterial function [169, 170]. In addition, the cytokine activity of type B lymphocytes is inhibited by mesenchymal stem cells [153]. Mesenchymal stem cells help regenerate the capillary barrier, which protects alveolar cells through the action of growth and secretion factors $[171,172]$. MSC-EV therapy was associated with immunoregulatory control in ALI models produced in mice [173]. The antibacterial effect of MSC is further demonstrated in inhibiting bacterial growth [174]. Numerous clinical trials have been conducted to evaluate the therapeutic benefits of MSCs and MSCs produced from MSCs in animal models of ALI, ARDS, and other lung inflammatory diseases $[175,176]$. These results demonstrated a substantial decrease in inflammatory responses, increased oedema secretion, and epithelial damage regeneration [177].

According to a pre-clinical investigation, intravenous Infusion of mesenchymal stem cells increased access to the alveolar epithelium and pulmonary endothelium $[178,179]$. One of the most lethal outcomes of SARSCOV-2 infection is an excessive immunological response, which, coupled with cytokine storms and acute respiratory distress syndrome, results in the failure and death of various bodily tissues, including the lungs [180-182]. Following intravenous injection, mesenchymal stem cells are confined in the injured lung and work directly with it to balance the immune system [183, 184]. The use of these cells can be effective in initiating a cytokine storm [185]. A peripheral or central vein is used to inject the cell. In some cases, cells can enter through the trachea [186]. Therefore, it can be considered that intratracheal administration may work better in Covid-19 patients [187]. However, all clinical trials to date have employed the intravenous injection of MSCs (Table 1), and the feasibility and efficacy of MSC delivery via intratracheal/ bronchial injection remain unclear [188, 189]. Mesenchymal stem cells have been shown in pre-clinical investigations to be effective in the treatment of lung damage and

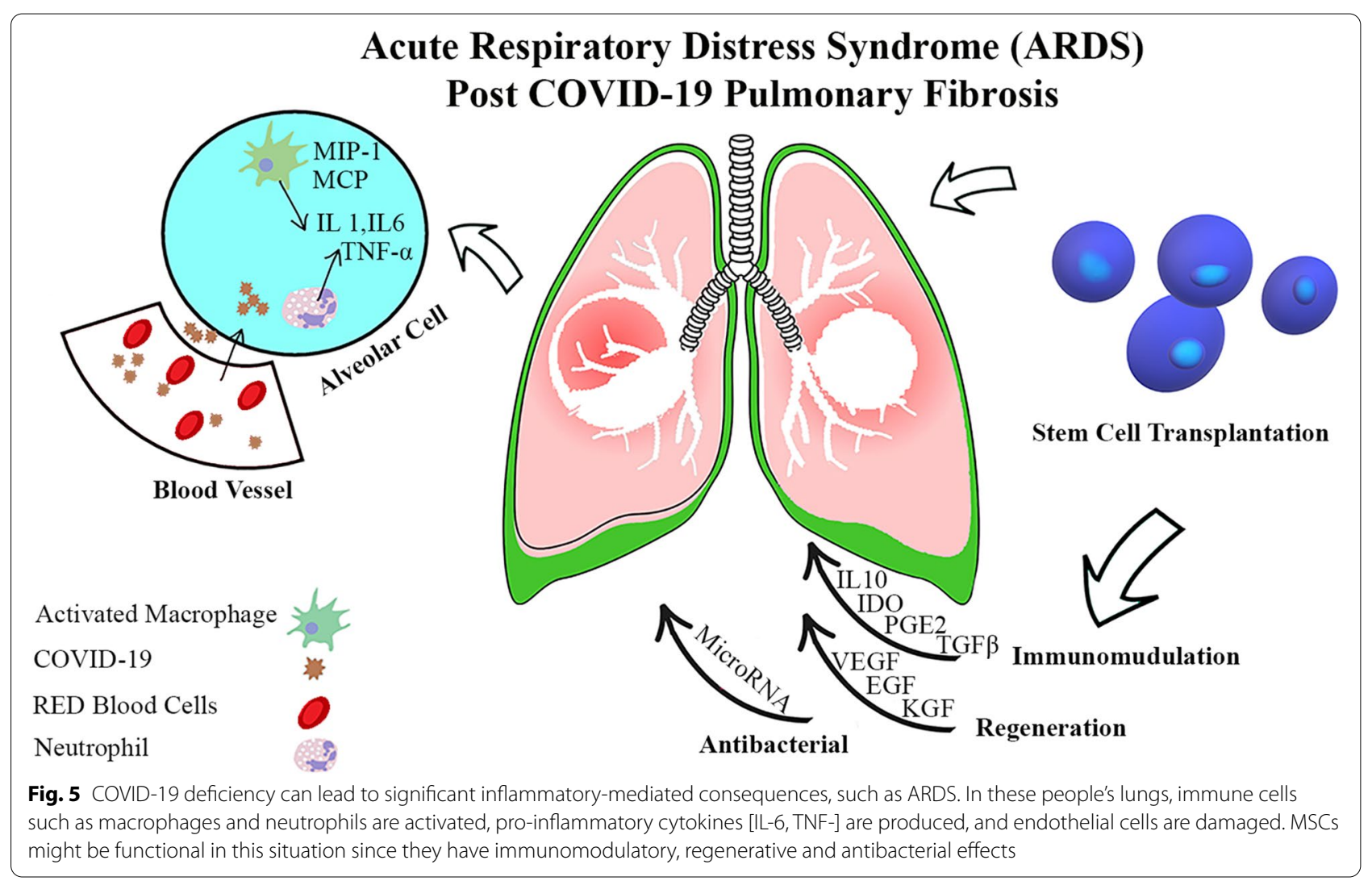


ARDS [190]. MSC treatment has been proven to lower inflammatory cytokines such as IL-1, IL-1, IL-6, IFN-, and TNF- It becomes and boosts anti-inflammatory cytokines such as IL-4. However, in-vivo models have not yet revealed the specific mechanism of action. By raising alveolar air volume and decreasing alveolar thickness and inflammatory indicators, IL-5 and IL-10 help heal lung epithelial cell injury and improve alveolar fluid secretion. Since MSCs can contribute to enhanced performance, it must be stated [191-196]. If the results of preliminary investigations are verified in larger studies, mesenchymal stem cells may have a role in the therapy of illness by using derivatives of MSCs, such as medium or extracellular vesicles [197, 198].

\section{Conclusion}

Various treatments have been introduced to treat COVID-19 disease. They are using mesenchymal cells, one of the treatments method that has shown promising results in clinical trials. As a consequence of the broad outbreak of the COVID-19 sickness and the widespread usage of numerous drugs, this disease has been successfully treated in a variety of destinations. So far, the use of these drugs has not shown promising results, and the disease is currently causing many deaths so that in some countries, the resulting mortality rate is higher than $6 \%$. MSCs are one of the cells that modulate the immune system and, according to the mechanism described in this study, can play a critical role in the treatment of this fatal disease. Because researchers use immunosuppressive drugs (Tocilizumab) to alleviate COVID-19 symptoms in patients, these cells, as the mechanism of action, can significantly improve critical conditions. Using these cells has been reported in some viral diseases. The results of using these cells in viral diseases such as influenza have also been brilliant. Numerous studies are being conducted on these cells and their therapeutic role against COVID-19. This research has even progressed to phase 3. So far, the results have been satisfactory. It is hoped that these relevant results will be conclusive. Although the use of MSCs has shown positive effects, more research is needed to make widespread use of these.

\section{Acknowledgements \\ The authors would like to tank Iran University of Medical Science (IUMS) and Babol University of medical science (BUMS).}

\section{Code availability}

N/A (Not applicable)

\section{Availability of data and matrials}

All the data is available upon request.

\section{Authors' contributions}

All the authors contributed to the draft writing. All authors read and approved the final manuscript. Peiman Brouki Milan and Masoud Mozafari worked on idea development and supervised the project. All authors read and approved the final manuscript.

Funding

No funding was obtained for this research.

\section{Declarations}

Ethics approval and consent to participate

N/A (Not applicable).

Consent for publication

N/A (Not applicable).

\section{Competing interests}

The authors declare that they have no conflict of interest.

\section{Author details}

${ }^{1}$ Cellular and Molecular Research Centre, Iran University of Medical Sciences, Tehran, Iran. ${ }^{2}$ Department of Tissue Engineering and Regenerative Medicine, Faculty of Advanced Technologies in Medicine, Iran University of Medical Sciences, Tehran, Iran. ${ }^{3}$ Oncopathology Research Center, Iran University of Medical Sciences, Tehran, Iran. ${ }^{4}$ Present Address: Department of Molecular Medicine, Faculty of Advanced Technologies in Medicine, Iran University of Medical Sciences, Tehran, Iran. ${ }^{5}$ Babol University of Medical Sciences, Infection Diseases Centre, Mazandaran, Iran.

Received: 2 May 2021 Accepted: 22 December 2021

Published online: 17 February 2022

\section{References}

1. Zu ZY, Jiang MD, Xu PP, Chen W, Ni QQ, Lu GM, et al. Coronavirus disease 2019 (COVID-19): a perspective from China. Radiology. 2020:200490. https://doi.org/10.1148/radiol.2020200490

2. Rothan HA, Byrareddy SN. The epidemiology and pathogenesis of coronavirus disease (COVID-19) outbreak. J Autoimmun. 2020;102433. https://doi.org/10.1016/j.jaut.2020.102433.

3. Lu Q, Shi Y. Coronavirus disease (COVID-19) and neonate: what neonatologist need to know. J Med Virol. 2020;92(6):564-7. https://doi.org/10. 1002/jmv.25740.

4. Harapan H, Itoh N, Yufika A, Winardi W, Keam S, Te H, et al. Coronavirus disease 2019 (COVID-19): a literature review. J Infect Public Health. 2020;13(5):667-73. https://doi.org/10.1016/j.jiph.2020.03.019.

5. Yang W, Cao Q, Qin L, Wang X, Cheng Z, Pan A, et al. Clinical characteristics and imaging manifestations of the 2019 novel coronavirus disease (COVID-19): a multi-center study in Wenzhou city, Zhejiang. China J Infect. 2020;02(016). https://doi.org/10.1016/j.jinf.

6. Lauer SA, Grantz KH, Bi Q, Jones FK, Zheng Q, Meredith HR, et al. The incubation period of coronavirus disease 2019 (COVID-19) from publicly reported confirmed cases: estimation and application. Ann Intern Med. 2020;172(9):577-82. https://doi.org/10.7326/M20-0504.

7. Geleris J, Sun Y, Platt J, Zucker J, Baldwin M, Hripcsak G, et al. Observational study of hydroxychloroquine in hospitalized patients with Covid19. N Engl J Med 2020;2012410.https://doi.org/10.1056/NEJMoa2012 410

8. Ciotti M, Ciccozzi M, Terrinoni A, Jiang WC, Wang CB, Bernardini S. The COVID-19 pandemic. Crit Rev Clin Lab Sci. 2020;57(6):365-88. https:// doi.org/10.1080/10408363.2020.1783198.

9. Golchin A, Seyedjafari E, Ardeshirylajimi A. Mesenchymal stem cell therapy for COVID-19: present or future. Stem Cell Rev Rep. 2020;1-7. https://doi.org/10.1007/s12015-020-09973.

10. Xiao K, Hou F, Huang X, Li B, Qian ZR, Xie L. Mesenchymal stem cells: current clinical progress in ARDS and COVID-19. Stem Cell Res Ther. 2020;11(1):1-7. https://doi.org/10.1186/s13287-020-01804-6.

11. Carlson RH. Mesenchymal stem cells modulate immune system in GvHD patients. Oncology. Times. 2006;22. https://doi.org/10.1097/01. COT.0000316085.03570.ce. 
12. Can $\mathrm{A}$, Coskun $\mathrm{H}$. The rationale of using mesenchymal stem cells in patients with COVID-19 related acute respiratory distress syndrome: what to expect. Stem Cells Transl Med. 2020:20-0164. https://doi.org/ 10.1002/sctm.20-0164.

13. Yufang $S$, Wang $Y$, Changshun $S$, Jianan $H$, Jianhe $G$, Xiaoping $H$, et al. (COVID-19) infection: the perspectives on immune responses. Cell Death Differ. 2020:s41418-020-0530-3. https://doi.org/10.1038/ s41418-020-0530-3.

14. Williamson EJ, Walker AJ, Bhaskaran K, Bacon S, Bates C, Morton CE, et al. OpenSAFELY: factors associated with COVID-19 death in 17 million patients. Nature. 2020;584(7821):430. https://doi.org/10.1038/ s41586-020-2521-4.

15. Saldanha-Araujo F, Melgaço Garcez E, Silva-Carvalho AE, Carvalho JL. Mesenchymal stem cells: a new piece in the puzzle of COVID-19 treatment. Front Immunol. 2020;11:1563. https://doi.org/10.3389/fimmu. 2020.01563.

16. Gupta A, Kashte S, Gupta M, Rodriguez HC, Gautam SS, Kadam S. Mesenchymal stem cells and exosome therapy for COVID-19: current status and future perspective. Hum Cell. 2020;1-12. https://doi.org/10.1007/ s13577-020-00407-W.

17. Lim SK, Giebel B, Weiss DJ, Witwer KW, Rohde E, et al. Re: "Exosomes Derived from Bone Marrow Mesenchymal Stem Cells as Treatment for Severe COVID-19" by Sengupta. Stem Cells Dev. 2020;29(14):877-8. https://doi.org/10.1089/scd.2020.0089.

18. Li H, Liu S-M, Yu X-H, Tang S-L, Tang C-K. Coronavirus disease 2019 [COVID-19]: current status and future perspective. Int J Antimicrob Agents. 2020:105951. https://doi.org/10.1016/j.ijantimicag.2020.105951.

19. Tyrrell D, Bynoe M. Cultivation of viruses from a high proportion of patients with colds. Lancet. 1966:76-7. https://doi.org/10.1016/s01406736(66)92364-6.

20. Velavan TP, Meyer CG. The COVID-19 epidemic. Tropical Med Int Health. 2020;25(3):278. https://doi.org/10.1111/tmi.13383.

21. Tu H, Tu S, Gao S, Shao A, Sheng J. The epidemiological and clinical features of COVID-19 and lessons from this global infectious public health event. J Inf Secur. 2020;1588076901. https://doi.org/10.1016/j.jinf.2020. 04.011.

22. Butler MJ, Barrientos RM. The impact of nutrition on COVID-19 susceptibility and long-term consequences. Brain Behav Immun. 2020;87:53-4. https://doi.org/10.1016/j.bbi.2020.04.040.

23. Rana A, Oliveira MP, Khamoui AV, Aparicio R, Rera M, Rossiter HB, et al. Promoting drp1-mediated mitochondrial fission in midlife prolongs healthy lifespan of drosophila melanogaster. Nat Commun. 2017;8(1):448. https://doi.org/10.1038/s41467-017-00525-4.

24. Livingston E, Bucher K. Coronavirus disease 2019 [COVID-19] in Italy. Jama. 2020;323(14):1335. https://doi.org/10.1001/jama.2020.4344.

25. Tian S, Hu N, Lou J, Chen K, Kang X, Xiang Z, et al. Characteristics of COVID-19 infection in Beijing. J Inf Secur. 2020;80(4):401-6. https://doi. org/10.1016/j.jinf.2020.02.018.

26. Bai HX, Hsieh B, Xiong Z, Halsey K, Choi JW, Tran TML, et al. Performance of radiologists in differentiating COVID-19 from viral pneumonia on chest CT. Radiology. 2020;296(2):E46-54. https://doi.org/10.1148/radiol. 2020200823.

27. Peiris JS, Yuen KY, Osterhaus AD, Stohr K. The severe acute respiratory syndrome. N Engl J Med. 2003;349(25):2431-41. https://doi.org/10. 1056/NEJMra032498.

28. Avula A, Nalleballe K, Narula N, Sapozhnikov S, Dandu V, Toom S, et al. COVID-19 presenting as stroke. Brain Behav Immun. 2020;87:115-9. https://doi.org/10.1016/j.bbi.2020.04.077.

29. Gostic K, Gomez AC, Mummah RO, Kucharski AJ, Lloyd-Smith JO. Estimated effectiveness of symptom and risk screening to prevent the spread of COVID-19. Elife. 2020;9:e55570. https://doi.org/10.7554/eLife.55570.

30. Cristina M, Valdes Ana M, Freidin Maxim B, Carole S, Nguyen H, Long $\mathrm{H}$. Real-time tracking of self-reported symptoms to predict potential COVID-19. Nat Med. 2020:04.05.20048421v1. https://doi.org/10.1038/ s41591-020-0916-2.

31. Goyal P, Choi JJ, Pinheiro LC, Schenck EJ, Chen R, Jabri A, et al. Clinical characteristics of Covid-19 in New York city. N Engl J Med. 2020;382(24):2372-4. https://doi.org/10.1056/NEJMc2010419.

32. Song Y, Liu P, Shi X, Chu Y, Zhang J, Xia J, et al. SARS-COV-2 induced diarrhoea as onset symptom in patient with COVID-19. Gut. 2020;69(6):1143-4. https://doi.org/10.1136/gutjnl-2020-320891.
33. Tobin MJ, Laghi F, Jubran A. Why COVID-19 silent hypoxemia is baffling to physicians. Am J Respir Crit Care Med. 2020;202(3):356-60. https:// doi.org/10.1164/rccm.202006-2157CP.

34. Bulut C, Kato Y. Epidemiology of COVID-19. Turkish J Med Sci. 2020;50(SI-1):563-70. https://doi.org/10.3906/sag-2004-172.

35. Tufan A, GÜLER AA, Matucci-Cerinic M. COVID-19, immune system response, hyperinflammation and repurposing antirheumatic drugs. Turkish J Med Sci. 2020;50(SI-1):620-32. https://doi.org/10.3906/ sag-2004-168.

36. Jawhara S. Could Intravenous immunoglobulin collected from recovered coronavirus patients protect against COVID-19 and strengthen the immune system of new patients? Int J Mol Sci. 2020;21(7):2272. https:// doi.org/10.3390/ijms21072272.

37. Mehta P, McAuley DF, Brown M, Sanchez E, Tattersall RS, Manson JJ, et al. COVID-19: consider cytokine storm syndromes and immunosuppression. Lancet. 2020;395(10229):1033. https://doi.org/10.1016/S01406736(20)30628-0.

38. Tandon R. The COVID-19 pandemic, personal reflections on editorial responsibility. Asian J Psychiatr. 2020;50:102100. https://doi.org/10. 1016/j.ajp.2020.102100

39. Wu KE, Fazal FM, Parker KR, Zou J, Chang HY. Rna-gps predicts SARSCOV-2 rna residency to host mitochondria and nucleolus. Cell Syst. 2020;11(1):102-8 e103. https://doi.org/10.1016/j.cels.2020.06.008.

40. Oyelade T, Alqahtani J, Canciani G. Prognosis of COVID-19 in patients with liver and kidney diseases: an early systematic review and metaanalysis. Trop Med Infect Dis. 2020;5(2):80. https://doi.org/10.3390/tropi calmed5020080.

41. Cai J, Wu J, Wang J, Li Y, Hu X, Luo S, et al. Extracellular vesicles derived from different sources of mesenchymal stem cells: therapeutic effects and translational potential. Cell Biosci. 2020;10:1-4. 10:1-14. https://doi. org/10.1186/s13578-020-00427-x.

42. $\mathrm{Hu} \mathrm{C,} \mathrm{Wu} \mathrm{Z,} \mathrm{Li} \mathrm{L.} \mathrm{Pre} \mathrm{treatments} \mathrm{enhance} \mathrm{the} \mathrm{therapeutic} \mathrm{effects} \mathrm{of}$ mesenchymal stem cells in liver diseases. J Cell Mol Med. 2020;24(1):409. https://doi.org/10.1111/jcmm.14788.10.1111/jcmm.14788.

43. Xu J, Chen J, Li W, Lian W, Huang J, Lai B, et al. Additive therapeutic effects of mesenchymal stem cells and IL-37 for systemic lupus erythematosus. J Am Soc Nephrol. 2020;31(1):54-65. https://doi.org/10.1681/ ASN.2019050545

44. Chamberlain G, Fox J, Ashton B, Middleton J. Concise review: mesenchymal stem cells: their phenotype, differentiation capacity, immunological features, and potential for homing. Stem Cells. 2007;25(11):2739-49. https://doi.org/10.1634/stemcells.2007-0197.

45. Maxson S, Lopez EA, Yoo D, Danilkovitch-Miagkova A, LeRoux MA. Concise review: role of mesenchymal stem cells in wound repair. Stem Cells Transl Med. 2012;1(2):142-9. https://doi.org/10.5966/sctm. 2011-0018.

46. Yang R, Huang H, Cui S, Zhou Y, Zhang T, Zhou Y. IFN- $Y$ promoted exosomes from mesenchymal stem cells to attenuate colitis via miR125a and miR-125b. Cell Death Dis. 2020;11(7):1-12. https://doi.org/10. 1038/s41419-020-02788-0.

47. Lukomska B, Stanaszek L, Zuba-Surma E, Legosz P, Sarzynska S, Drela K. Challenges and controversies in human mesenchymal stem cell therapy. Stem Cells Int. 2019;9628536. https://doi.org/10.1155/2019/ 9628536.

48. Öztürk S, Elçin AE, Elçin YM. Mesenchymal stem cells for coronavirus [COVID-19]-induced pneumonia: revisiting the paracrine hypothesis with new hopes? Aging Dis. 2020;11(3):477. https://doi.org/10.14336/ AD.2020.0403.

49. Suvakov S, Richards C, Nikolic V, Simic T, McGrath K, Krasnodembskaya $A$, et al. Emerging therapeutic potential of mesenchymal stem/stromal cells in preeclampsia. Curr Hypertens Rep. 2020;22(5):1-13. https://doi. org/10.1007/s11906-020-1034-8.

50. Liu Y, Cui J, Wang H, Hezam K, Zhao X, Huang H, et al. Enhanced therapeutic effects of MSC-derived extracellular vesicles with an injectable collagen matrix for experimental acute kidney injury treatment. Stem Cell Res Ther. 2020;11(1):1-12. https://doi.org/10.1186/ s13287-020-01668-w.

51. Silva LH, Antunes MA, Dos Santos CC, Weiss DJ, Cruz FF, Rocco PR. Strategies to improve the therapeutic effects of mesenchymal stromal cells in respiratory diseases. Stem Cell Res Ther. 2018;9(1):1-9. https:// doi.org/10.1186/s13287-018-0802-8. 
52. Bier A, Berenstein P, Kronfeld N, Morgoulis D, Ziv-Av A, Goldstein H, et al. Placenta-derived mesenchymal stromal cells and their exosomes exert therapeutic effects in Duchenne muscular dystrophy. Biomaterials. 2018;174:67-78. https://doi.org/10.1016/j.biomaterials.2018.04.055.

53. Ma X, Liu J, Yang X, Fang K, Zheng P, Liang X, et al. Mesenchymal stem cells maintain the stemness of colon cancer stem cells via interleukin-8/ mitogen-activated protein kinase signaling pathway. Exp Biol Med. 2020;245(6):562-75. https://doi.org/10.1177/1535370220910690.

54. Hmadcha A, Martin-Montalvo A, Gauthier BR, Soria B, Capilla-Gonzalez $\checkmark$. Therapeutic potential of mesenchymal stem cells for Cancer therapy. Front Bioeng Biotechnol. 2020;8:43. https://doi.org/10.3389/fbioe.2020. 00043.

55. Song Y, Dou H, Li X, Zhao X, Li Y, Liu D, et al. Exosomal miR 146a contributes to the enhanced therapeutic efficacy of interleukin $1 \beta$ primed mesenchymal stem cells against sepsis. Stem Cells. 2017;35(5):1208-21. https://doi.org/10.1002/stem.2564.

56. Xie Z, Ye G, Wang P, Li J, Liu W, Li M, et al. Interleukin-6/interleukin-6 receptor complex promotes osteogenic differentiation of bone marrow-derived mesenchymal stem cells. Stem Cell Res Ther. 2018;9(1):110. https://doi.org/10.1186/s13287-017-0766-0.

57. Wang J, Ren H, Yuan X, Ma H, Shi X, Ding Y. Interleukin 10 secreted by mesenchymal stem cells attenuates acute liver failure through inhibiting pyroptosis. Hepatol Res. 2018;48(3):E194-202. https://doi.org/10. 1111/hepr.12969.

58. Thanunchai M, Hongeng S, Thitithanyanont A. Mesenchymal stromal cells and viral infection. Stem Cells Int. 2015;860950. https://doi.org/10. $1155 / 2015 / 860950$

59. Gao W-X, Sun Y-Q, Shi J, Li C-L, Fang S-B, Wang D, et al. Effects of mesenchymal stem cells from human induced pluripotent stem cells on differentiation, maturation, and function of dendritic cells. Stem Cell Res Ther. 2017:8(1):1-16. https://doi.org/10.1186/s13287-017-0499-0.

60. Romano B, Elangovan S, Erreni M, Sala E, Petti L, Kunderfranco P, et al. TNF stimulated gene is a key regulator in switching stemness and biological properties of mesenchymal stem cells. Stem Cells. 2019;37(7):973-87. https://doi.org/10.1002/stem.3010.

61. Yang H-M, Song W-J, Li Q, Kim S-Y, Kim H-J, Ryu M-O, et al. Canine mesenchymal stem cells treated with TNF- $a$ and IFN- $\gamma$ enhance antiinflammatory effects through the COX-2/PGE2 pathway. Res Vet Sci. 2018;119:19-26. https://doi.org/10.1016/j.rvsc.2018.05.011.

62. Wang X, Liang T, Qiu J, Qiu X, Gao B, Gao W, et al. Melatonin reverses the loss of stemness induced by TNF-a in human bone marrow mesenchymal stem cells through upregulation of YAP expression. Stem Cells Int. 2019;6568394. https://doi.org/10.1155/2019/6568394.

63. Qi K, Li N, Zhang Z, Melino G. Tissue regeneration: the crosstalk between mesenchymal stem cells and immune response. Cell Immunol. 2018;326:86-93. https://doi.org/10.1016/j.cellimm.2017.11.010.

64. Hu C, Li L. The immunoregulation of mesenchymal stem cells plays a critical role in improving the prognosis of liver transplantation. J Transl Med. 2019;17(1):1-12. https://doi.org/10.1186/s12967-019-02167-0.

65. O'Driscoll $L$. Extracellular vesicles from mesenchymal stem cells as a Covid-19 treatment. Drug Discov Today. 2020;25(7):1124. https://doi. org/10.1016/j.drudis.2020.04.022.

66. Jayaramayya K, Mahalaxmi I, Subramaniam MD, Raj N, Dayem AA, Lim KM, et al. Immunomodulatory effect of mesenchymal stem cells and mesenchymal stem-cell-derived exosomes for COVID-19 treatmen. BMB Rep. 2020;53(8):400. https://doi.org/10.5483/BMBRep.2020.53.8. 121.

67. Lee HY, Hong IS. Double-edged sword of mesenchymal stem cells: cancerpromoting versus therapeutic potential. Cancer Sci. 2017;108(10):1939-46. https://doi.org/10.1111/cas.13334.

68. Li H, Shen S, Fu H, Wang Z, Li X, Sui X, et al. Immunomodulatory functions of mesenchymal stem cells in tissue engineering. Stem Cells Int. 2019;9671206. https://doi.org/10.1155/2019/9671206.

69. Wang M, Yuan Q, Xie L. Mesenchymal stem cell-based immunomodulation: properties and clinical application. Stem Cells Int. 2018;3057624. https://doi.org/10.1155/2018/3057624.

70. Heo JS, Choi Y, Kim HO. Adipose-derived mesenchymal stem cells promote M2 macrophage phenotype through exosomes. Stem Cells Int. 2019;7921760. https://doi.org/10.1155/2019/7921760.

71. Jiang W, Xu J. Immune modulation by mesenchymal stem cells. Cell Prolif. 2020;53(1):e12712. https://doi.org/10.1111/cpr.12712.
72. Li Y, Zhang D, Xu L, Dong L, Zheng J, Lin Y, et al. Cell-cell contact with pro-inflammatory macrophages enhances the immunotherapeutic effect of mesenchymal stem cells in two abortion models. Cell Mol Immunol. 2019;16(12):908-20. https://doi.org/10.1038/ s41423-019-0204-6.

73. Orciani M, Campanati A, Caffarini M, Ganzetti G, Consales V, Lucarini G, et al. Thelper [Th] 1, Th17 and Th2 imbalance in mesenchymal stem cells of adult patients with atopic dermatitis: at the origin of the problem. Br J Dermatol. 2017;176(6):1569-76. https://doi.org/10.1111/bjd. 15078.

74. Kuca-Warnawin E, Janicka I, Bonek K, Kontny E. Modulatory impact of adipose-derived mesenchymal stem cells of ankylosing spondylitis patients on Thelper cell differentiation. Cells. 2021;10(2):280. https:// doi.org/10.3390/cells10020280.

75. Dahiya DS, Kichloo A, Albosta M, Pagad S, Wani F. Gastrointestinal implications in covid-19. J Investig Med. 2020;68(8):1397-401. https:// doi.org/10.1136/jim-2020-001559.

76. Geng L, Tang X, Wang S, Sun Y, Wang D, Tsao BP, et al. Reduced let-7f in bone marrow-derived mesenchymal stem cells triggers Treg/Th17 imbalance in patients with systemic lupus erythematosus. Front Immunol. 2020;11:233. https://doi.org/10.3389/fimmu.2020.00233.

77. Zhang W, Zhou L, Dang J, Zhang X, Wang J, Chen Y, et al. Human gingiva-derived mesenchymal stem cells ameliorate streptozoticininduced T1DM in mice via suppression of T effector cells and upregulating Treg subsets. Sci Rep. 2017;7(1):1-12. https://doi.org/10. 1038/s41598-017-14979-5.

78. Chrzanowski W, Kim SY, McClements L. Can stem cells beat COVID-19: advancing stem cells and extracellular vesicles toward mainstream medicine for lung injuries associated with SARS-COV-2 infections. Front Bioeng Biotechnol. 2020;8:554. https://doi.org/10.3389/fbioe.2020. 00554.

79. Zhao K, Liu Q. The clinical application of mesenchymal stromal cells in hematopoietic stem cell transplantation. J Hematol Oncol. 2016;9(1):46. https://doi.org/10.1186/s13045-016-0276-z.

80. Rizvanov AA, Persson J, Sahin F, Bellusci S, Oliveira PJ. Hematopoietic and mesenchymal stem cells in biomedical and clinical applications. 2016;3157365. https://doi.org/10.1155/2016/3157365.

81. Ottaviano G, Chiesa R, Feuchtinger T, Vickers MA, Dickinson A, Gennery AR, et al. Adoptive T cell therapy strategies for viral infections in patients receiving haematopoietic stem cell transplantation. Cells. 2019;8(1):47. https://doi.org/10.3390/cells8010047.

82. Düver F, Weißbrich B, Eyrich M, Wölfl M, Schlegel PG, Wiegering V. Viral reactivations following hematopoietic stem cell transplantation in pediatric patients-a single center 11-year analysis. PLoS One. 2020;15(2):e0228451. https://doi.org/10.1371/journal.pone.0228451.

83. Liang B, Li T, Wu H, Yang W, Li Y, Li J, et al. Clinical remission of a critically ill COVID-19 patient treated by human umbilical cord mesenchymal stem cells. 2020;99(31). https://doi.org/10.1097/MD.0000000000021429.

84. Metcalfe SM. Mesenchymal stem cells and management of COVID-19 pneumonia. Med Drug Discovery. 2020;100019. https://doi.org/10. 1016/j.medidd.2020.100019.

85. Novello S, Debouche A, Philippe M, Naudet F, Jeanne S. Clinical application of mesenchymal stem cells in periodontal regeneration: a systematic review and meta analysis. J Periodontal Res. 2020;55(1):1-12. https://doi.org/10.1111/jre.12684.

86. Gavriatopoulou M, Korompoki E, Fotiou D, Ntanasis-Stathopoulos I, Psaltopoulou T, Kastritis E, et al. Organ-specific manifestations of covid19 infection. Clin Exp Med. 2020;20(4):493-506. https://doi.org/10.1007/ s10238-020-00648-X.

87. Wong JE, Leo YS, Tan CC. COVID-19 in Singapore-current experience: critical global issues that require attention and action. Jama. 2020;323(13):1243-4. https://doi.org/10.1001/jama.2020.2467.

88. Zhu F, Xia Z-F. Paracrine activity of stem cells in therapy for acute lung injury and adult respiratory distress syndrome. J Trauma Acute Care Surg. 2013;74(5):1351-6. https://doi.org/10.1097/TA.0b013e3182 83d942.

89. Serikov VB, Krasnodembskaya A, Lee JW, Eldridge MW, Matthay MA. MSCs for treatment of acute lung injury. Mesenchymal Stromal Cells: Springer; 2013; p. 561-70. https://doi.org/10.1007/978-1-4614-5711-4.

90. Du J, Li H, Lian J, Zhu X, Qiao L, Lin J. Stem cell therapy: a potential approach for treatment of influenza virus and coronavirus-induced 
acute lung injury. Stem Cell Res Ther 2020;11[1]:1-9. https://doi.org/10. 1186/s13287-020-01699-3.

91. Guido M, Norman D, Julian K-M, Sven G, Hans-Dieter V, Petra R. MSC therapies for COVID-19: importance of patient coagulopathy, Thromboprophylaxis, cell product quality and mode of delivery for treatment safety and efficacy. Front Immunol. 2020;11:1091. https://doi.org/10. 3389/fimmu.2020.01091.

92. Chen J, Hu C, Chen L, Tang L, Zhu Y, Xu X. Clinical study of mesenchymal stem cell treatment for acute respiratory distress syndrome induced by epidemic influenza a [H7N9] infection: a hint for COVID-19 treatment. Engineering. 2020;6(10):1153-61. https://doi.org/10.1016/j.eng.2020.02. 006.

93. Khoury M, Cuenca J, Cruz FF, Figueroa FE, Rocco PR, Weiss DJ. Current status of cell-based therapies for respiratory virus infections: applicability to COVID-19. Eur Respir J. 2020;55(6). https://doi.org/10.1183/13993 003.00858-2020.

94. Shafei AES, Ali MA, Ghanem HG, Shehata Al, Abdelgawad AA, Handal $H R$, et al. Mesenchymal stem cell therapy: a promising cell based therapy for treatment of myocardial infarction. The. J Gene Med. 2017;19(12):e2995. https://doi.org/10.1002/jgm.2995.

95. Han J, Liu Y, Liu H, Li Y. Genetically modified mesenchymal stem cell therapy for acute respiratory distress syndrome. Stem Cell Res Ther. 2019;10(1):386. https://doi.org/10.1186/s13287-019-1518-0.

96. Qu W, Wang Z, Hare JM, Bu G, Mallea JM, Pascual JM, et al. Cell based therapy to reduce mortality from COVID-19: systematic review and meta analysis of human studies on acute respiratory distress syndrome. Stem Cells Transl Med. 2020;9(9):1007-22. https://doi.org/10.1002/sctm. 20-0146.

97. Zhao RC. Stem Cell-Based Therapy for Coronavirus Disease 2019. Stem Cells Dev. 2020. https://doi.org/10.1089/scd.2020.0071.

98. Montelongo-Jauregui D, Vila T, Sultan AS, Jabra-Rizk MA. Convalescent serum therapy for COVID-19: a 19th century remedy for a 21st century disease. PLoS Pathog. 2020;16(8):e1008735. https://doi.org/10.1371/ journal.ppat.1008735.

99. Daly JL, Simonetti B, Klein K, Chen KE, Williamson MK, Anton-Plagaro C, et al. Neuropilin-1 is a host factor for SARS-COV-2 infection. Science. 2020;370(6518):861-5. https://doi.org/10.1126/science.abd3072.

100. Jethani B, Gupta M, Wadhwani P, Thomas R, Balakrishnan T, Mathew $G$, et al. Clinical characteristics and remedy profiles of patients with COVID-19: a retrospective cohort study. Homeopathy. 2021;110(02):086-93. https://doi.org/10.1055/s-0040-1718584.

101. Doggrell SA. Remdesivir, a remedy or a ripple in severe COVID-19. Expert Opin Invest Drug. 2020;29(11):1195-8. https://doi.org/10.1080/ 13543784.2020 .1821645

102. Prajapati S. Isopathic remedy prepared from convalescent plasma as a therapeutic option for COVID-19? Homeopathy. 2020;109(03):184-5. https://doi.org/10.1055/s-0040-1714061.

103. Cantuti-Castelvetri L, Ojha R, Pedro LD, Djannatian M, Franz J, Kuivanen S, et al. Neuropilin-1 facilitates SARS-COV-2 cell entry and infectivity. Science. 2020;370(6518):856-60. https://doi.org/10.1126/science.abd29 85.

104. Lin R, Heylbroeck C, Pitha PM, Hiscott J. Virus-dependent phosphorylation of the irf-3 transcription factor regulates nuclear translocation, transactivation potential, and proteasome-mediated degradation. Mo Cell Biol. 1998;18(5):2986-96. https://doi.org/10.1128/mcb.18.5.2986.

105. Lanzoni G, Linetsky E, Correa D, Messinger Cayetano S, Alvarez RA, Kouroupis D, et al. Cells for COVID-19 acute respiratory distress syndrome: a double-blind, phase 1/2a, randomized controlled trial. Stem Cells Transl Med. 2021;10(5):660-73. https://doi.org/10.1002/sctm.20-0472.

106. Peyravian N, Malekzadeh Kebria M, Kiani J, Brouki Milan P, Mozafari M. CRISPR-associated (CAS) effectors delivery via microfluidic cell-deformation Chip. Materials. 2021;14(12):3164. https://doi.org/10.3390/ma141 23164.

107. Coban MA, Morrison J, Maharjan S, Hernandez Medina DH, Li W, Zhang YS, et al. Attacking COVID-19 progression using multi-drug therapy for synergetic target engagement. Biomolecules. 2021;11(6):787. https:// doi.org/10.3390/biom11060787.

108. Sönmez Güngör E, Yalçın $M$, Yerebakan Tüzer $M$, Beşikçi Keleş D, Öcek Baş T, Ergelen M, et al. Adverse drug reactions associated with concurrent acute psychiatric treatment and Covid-19 drug therapy. Int J
Psychiatry Clin Pract. 2021;25(2):142-6. https://doi.org/10.1080/13651 501.2020.1843182.

109. Abhyankar MA, Kumar SH, Kumar BK, Swain SK, Walavalkar AM, Silki SI. Triple drug therapy to manage uncontrolled BP in hypertensive patients during Covid-19 lockdown: perspectives from India. Eur J Cardiovasc Nurs. 2021;20(Supplement_1):zvab060-030. https://doi.org/ 10.1093/eurjen/zvab060.030.

110. Adeghate EA, Eid N, Singh J. Mechanisms of COVID-19-induced heart failure: a short review. Heart Fail Rev. 2021;26(2):363-9. https://doi.org/ 10.1007/s10741-020-10037-x.

111. Mohamed K, Yazdanpanah N, Saghazadeh A, Rezaei N. Computational drug discovery and repurposing for the treatment of COVID-19: a systematic review. Bioorg Chem. 2021;106:104490. https://doi.org/10. 1016/j.bioorg.2020.104490.

112. Dai L, Gao G. Viral targets for vaccines against COVID-19. Nat Rev Immunol. 2021;21(2):73-82. https://doi.org/10.1038/ s41577-020-00480-0.

113. Godino C, Scotti A, Maugeri N, Mancini N, Fominskiy E, Margonato A, et al. Antithrombotic therapy in patients with COVID-19?-rationale and evidence. Int J Cardiol. 2021;1 (324):261-6. https://doi.org/10.1016/j. ijcard.2020.09.064.

114. Katagiri D, Ishikane M, Ogawa T, Kinoshita N, Katano H, Suzuki T, et al. Continuous renal replacement therapy for a patient with severe COVID19. Blood Purif. 2021;50(1):129-31. https://doi.org/10.1159/000508062.

115. Aziz A, Asif M, Ashraf G, Yang Q, Wang S. COVID-19 impacts, diagnosis and possible therapeutic techniques: a comprehensive review. Curr Pharm Des. 2021;27(9):1170-84. https://doi.org/10.2174/1874467213 666201204154239.

116. Noce A, Albanese M, Marrone G, Di Lauro M, Pietroboni Zaitseva A, Palazzetti D, et al. Ultramicronized palmitoylethanolamide [um-PEA]: a new possible adjuvant treatment in COVID-19 patients. Pharmaceuticals. 2021;14(4):336. https://doi.org/10.3390/ph14040336.

117. Dai L, Zheng T, Xu K, Han Y, Xu L, Huang E, et al. A universal design of betacoronavirus vaccines against COVID-19, MERS, and SARS. Cell. 2020;182(3):722-33.e11. https://doi.org/10.1016/j.cell.2020.06.035

118. LiT, Qiu Z, Zhang L, Han Y, He W, Liu Z, et al. Significant changes of peripheral t lymphocyte subsets in patients with severe acute respiratory syndrome. J Infect Dis. 2004;189(4):648-51. https://doi.org/10. 1086/381535

119. Li H, Zheng S, Liu F, Liu W, Zhao R. Fighting against COVID-19: innovative strategies for clinical pharmacists. Res Soc Adm Pharm. 2021:17(1):1813-8. https://doi.org/10.1016/..sapharm.2020.04.003.

120. Kumar P, Sah AK, Tripathi G, Kashyap A, Tripathi A, Rao R, et al. Role of ACE2 receptor and the landscape of treatment options from convalescent plasma therapy to the drug repurposing in COVID19. Mol Cell Biochem. 2021;476(2):553-74. https://doi.org/10.1007/ s11010-020-03924-2.

121. Fominskiy EV, Scandroglio AM, Monti G, Calabrò MG, Landoni G, et al. Prevalence, characteristics, risk factors, and outcomes of invasively ventilated COVID-19 patients with acute kidney injury and renal replacement therapy. Blood Purif. 2021;50(1):102-9. https://doi.org/10. $1159 / 000508657$.

122. Iwanami S, Ejima K, Kim KS, Noshita K, Fujita Y, Miyazaki T, et al. Detection of significant antiviral drug effects on COVID-19 with reasonable sample sizes in randomized controlled trials: a modeling study. PLoS Med. 2021;18(7):e1003660. https://doi.org/10.1371/journal.pmed.10036 60.

123. Shao H, Lan D, Duan Z, Liu Z, Min J, Zhang L, et al. Upregulation of mitochondrial gene expression in pbmc from convalescent sars patients. J Clin Immunol. 2006;26(6):546-54. https://doi.org/10.1007/ s10875-006-9046-y.

124. Zhou N, Yang X, Huang A, Chen Z. The potential mechanism of $\mathrm{N}$-acetylcysteine in treating COVID-19. Curr Pharm Biotechnol. 2021. https://doi.org/10.2174/1389201021999201228212043.

125. Little C, Cosetti MK. A narrative review of pharmacologic treatments for COVID-19: safety considerations and ototoxicity. Laryngoscope. 2021;131(7):1626-32. https://doi.org/10.1002/lary.29424.

126. Wong KK, Lee SW, Kua KP. N-acetylcysteine as adjuvant therapy for COVID-19-a perspective on the current state of the evidence. J Inflamm Res. 2021;14:2993. https://doi.org/10.2147/JIR.S306849. 
127. Mehra MR, Desai SS, Kuy S, Henry TD, Patel AN. Retraction: cardiovascular disease, drug therapy, and mortality in Covid-19. N Engl J Med. 2020;382:2582. https://doi.org/10.1056/NEJMoa2007621.

128. Naksuk N, Lazar S, Peeraphatdit T. Cardiac safety of off-label COVID-19 drug therapy: a review and proposed monitoring protocol. Eur Heart J Acute Cardiovasc Care. 2020;9(3):215-21. https://doi.org/10.1177/20488 72620922784

129. Sardu C, Maggi P, Messina V, luliano P, Sardu A, lovinella V, et al. Could anti hypertensive drug therapy affect the clinical prognosis of hypertensive patients with COVID-19 infection? Data from centers of southern Italy. J Am Heart Assoc. 2020;9(17):e016948. https://doi.org/ 10.1161/JAHA.120.016948.

130. Sommerstein R, Kochen MM, Messerli FH, Gräni C. Coronavirus disease 2019 [COVID-19]: do angiotensin converting enzyme inhibitors/angiotensin receptor blockers have a biphasic effect? J Am Heart Assoc. 2020;9(7):e016509. https://doi.org/10.1161/JAHA.120.016509.

131. Xu J, Huang C, Fan G, Liu Z, Shang L, Zhou F, et al. Use of angiotensinconverting enzyme inhibitors and angiotensin II receptor blockers in context of COVID-19 outbreak: a retrospective analysis. Front Med. 2020;14(5):601-12. https://doi.org/10.1007/s11684-020-0800-y.

132. Zhou F, Liu YM, Xie J, Li H, Lei F, Yang H, et al. Comparative impacts of ACE [angiotensin-converting enzyme] inhibitors versus angiotensin II receptor blockers on the risk of COVID-19 mortality. Hypertension. 2020;76(2):e15-7. https://doi.org/10.1161/HYPERTENSIONAHA.120. 15622.

133. Liu X, Long C, Xiong Q, Chen C, Ma J, Su Y, et al. Association of angiotensin converting enzyme inhibitors and angiotensin II receptor blockers with risk of COVID-19, inflammation level, severity, and death in patients with COVID19: a rapid systematic review and meta analysis. Clin Cardiol. 2020. https://doi.org/10.1002/clc.23421.

134. Bean DM, Kraljevic Z, Searle T, Bendayan R, Kevin OG, et al. Angiotensinconverting enzyme inhibitors and angiotensin II receptor blockers are not associated with severe COVID-19 infection in a multisite UK acute hospital trust. Eur J Heart Fail. 2020;22(6):967-74. https://doi.org/10. 1002/ejhf.1924.

135. Malone RW, Tisdall P, Fremont-Smith P, Liu Y, Huang XP, White KM, et al. COVID-19: famotidine, histamine, mast cells, and mechanisms. Front Pharmacol. 2021;12:216. https://doi.org/10.3389/fphar.2021.633680.

136. Falck-Jones S, Vangeti S, Yu M, Falck-Jones R, Cagigi A, Badolati I, et al. Functional monocytic myeloid-derived suppressor cells increase in blood but not airways and predict COVID-19 severity. J Clin Invest. 2021:131(6). https://doi.org/10.1172/JCl144734

137. Wenceslau CF, McCarthy CG, Goulopoulou S, Szasz T, NeSmith EG, Webb RC. Mitochondrial-derived n-formyl peptides: novel links between trauma, vascular collapse and sepsis. Med Hypotheses. 2013;81(4):532-5. https://doi.org/10.1016/j.mehy.2013.06.026.

138. Borges RC, Hohmann MS, Borghi SM. Dendritic cells in COVID-19 immunopathogenesis: insights for a possible role in determining disease outcome. Int Rev Immunol. 2021;40(1-2):108-25. https://doi.org/10. 1080/08830185.2020.1844195.

139. Kusnadi A, Ramírez-Suástegui C, Fajardo V, Chee SJ, Meckiff BJ, Simon $\mathrm{H}$, et al. Severely ill COVID-19 patients display impaired exhaustion features in SARS-CoV-2-reactive CD8+ T cells. Sci Immunol. 2021;6(55). https://doi.org/10.1101/2020.07.09.194027.

140. Esquivel D, Mishra R, Soni P, Seetharaman R, Mahmood A, Srivastava A Stem cells therapy as a possible therapeutic option in treating COVID19 patients. Stem Cell Rev Rep. 2021;17(1):144-52. https://doi.org/10. 1007/s12015-020-10017-6.

141. Bozzano F, Dentone C, Perrone C, Di Biagio A, Fenoglio D, Parodi A, et al. Extensive activation, tissue trafficking, turnover and functional impairment of NK cells in COVID-19 patients at disease onset associates with subsequent disease severity. PLoS Pathog. 2021;17(4):e1009448. https:// doi.org/10.1371/journal.ppat.1009448.

142. Wang Y, Zheng J, Islam MS, Yang Y, Hu Y, Chen X. The role of CD4+ FoxP3+ regulatory $T$ cells in the immunopathogenesis of COVID-19: implications for treatment. Int J Biol Sci. 2021;17(6):1507. https://doi. org/10.7150/ijbs.59534.

143. Zingaropoli MA, Nijhawan P, Carraro A, Pasculli P, Zuccalà P, Perri V, et al. Increased SCD163 and sCD14 plasmatic levels and depletion of peripheral blood pro-inflammatory monocytes, myeloid and plasmacytoid dendritic cells in patients with severe COVID-19 pneumonia. Front Immunol. 2021;12:147. https://doi.org/10.3389/fimmu.2021.627548.

144. Fadai NT, Sachak-Patwa R, Byrne HM, Maini PK, Bafadhel M, Nicolau DV Jr. Infection, inflammation and intervention: mechanistic modelling of epithelial cells in COVID-19. J R Soc Interface. 2021;18(175):20200950. https://doi.org/10.1098/rsif.2020.0950.

145. Rocha JL, de Oliveira WC, Noronha NC, Dos Santos NC, Covas DT, Picanço-Castro $V$, et al. Mesenchymal stromal cells in viral infections: implications for COVID-19. Stem Cell Rev Rep. 2021;17(1):71-93. https:// doi.org/10.1007/s12015-020-10032-7.

146. Zhang Q, Raoof M, Chen Y, Sumi Y, Sursal T, Junger W, et al. Circulating mitochondrial damps cause inflammatory responses to injury. Nature. 2010;464(7285):104-7. https://doi.org/10.1038/nature08780.

147. Bange EM, Han NA, Wileyto P, Kim JY, Gouma S, Robinson J, et al. CD8 T cells compensate for impaired humoral immunity in COVID-19 patients with hematologic cancer. Res Square. 2021. https://doi.org/10.21203/ rs.3.rs-162289/v1.

148. Saichi M, Ladjemi MZ, Korniotis S, Rousseau C, Hamou ZA, MassenetRegad $L$, et al. Single-cell RNA sequencing of blood antigen-presenting cells in severe COVID-19 reveals multi-process defects in antiviral immunity. Nat Cell Biol. 2021;(5):538-51. https://doi.org/10.1038/ s41556-021-00681-2.

149. Xu X, Jiang W, Chen L, Xu Z, Zhang Q, Zhu M, et al. Evaluation of the safety and efficacy of using human menstrual blood-derived mesenchymal stromal cells in treating severe and critically ill COVID-19 patients: an exploratory clinical trial. Clin Transl Med. 2021;11(2):e297. https://doi.org/10.1002/ctm2.297.

150. Goulopoulou S, Matsumoto T, Bomfim GF, Webb RC. Toll-like receptor 9 activation: a novel mechanism linking placenta-derived mitochondrial DNA and vascular dysfunction in pre-eclampsia. Clin Sci. 2012:123(7):429-35. https://doi.org/10.1042/CS20120130.

151. Varchetta S, Mele D, Oliviero B, Mantovani S, Ludovisi S, Cerino A, et al. Unique immunological profile in patients with COVID-19. Cell Mol Immunol. 2021;18(3):604-12. https://doi.org/10.1038/ s41423-020-00557-9.

152. Taniguchi-Ponciano K, Vadillo E, Mayani H, Gonzalez-Bonilla CR, Torres J, Majluf A, et al. Increased expression of hypoxia-induced factor 1 a mRNA and its related genes in myeloid blood cells from critically ill COVID-19 patients. Ann Med. 2021;53(1):197-207. https://doi.org/10. 1080/07853890.2020.1858234.

153. Stephenson E, Reynolds G, Botting RA, Calero-Nieto FJ, Morgan MD, Tuong ZK, et al. Single-cell multi-omics analysis of the immune response in COVID-19. Nat Med. 2021;27(5):904-16. https://doi.org/10. 1038/s41591-021-01329-2.

154. Cavalcante-Silva LH, Carvalho DC, de Almeida LÉ, Galvão JG, da Silva JS, de Sales-Neto JM, et al. Neutrophils and COVID-19: the road so far. Int Immunopharmacol. 2021;90:107233. https://doi.org/10.1016/j.intimp. 2020.107233.

155. Kalfaoglu B, Almeida-Santos J, Tye CA, Satou Y, Ono M. T-cell dysregulation in COVID-19. Biochem Biophys Res Commun. 2021;538:204-10. https://doi.org/10.1016/j.bbrc.2020.10.079.

156. Paital B, Agrawal PK. Air pollution by NO 2 and PM 2.5 explains COVID-19 infection severity by overexpression of angiotensinconverting enzyme 2 in respiratory cells: a review. Environ Chem Lett. 2021;19(1):25-42. https://doi.org/10.1007/s10311-020-01091-w.

157. Kvedaraite E, Hertwig L, Sinha I, Ponzetta A, Myrberg $I H$, Lourda M, et al. Major alterations in the mononuclear phagocyte landscape associated with COVID-19 severity. Proc Natl Acad Sci. 2021;118(6). https://doi.org/ $10.1073 /$ pnas.2018587118.

158. Rezaei M, Marjani M, Mahmoudi S, Mortaz E, Mansouri D. Dynamic changes of lymphocyte subsets in the course of covid-19. Int Arch Allergy Immunol. 2021;182(3):254-62. https://doi.org/10.1159/00051 4202.

159. Gorman E, Millar J, McAuley D, O'Kane C. Mesenchymal stromal cells for acute respiratory distress syndrome [ARDS], sepsis, and COVID-19 infection: optimizing the therapeutic potential. Expert Rev Respir Med. 2021;15(3):301-24.

160. Dean MJ, Ochoa JB, Sanchez-Pino M, Zabaleta J, Garai J, Del Valle L, et al. Transcriptome and Functions of Granulocytic Myeloid-Derived Suppressor Cells Determine their Association with Disease Severity of 
COVID-19. medRxiv. 2021:03.26.21254441v1. https://doi.org/10.1101/ 2021.03.26.21254441.

161. Acosta-Ampudia Y, Monsalve DM, Rojas M, Rodríguez Y, Gallo JE, Salazar-Uribe JC, et al. COVID-19 convalescent plasma composition and immunological effects in severe patients. J Autoimmun. 2021;118:102598. https://doi.org/10.1016/j.jaut.2021.102598.

162. Boechat $\mathrm{JL}$, Chora I, Morais A, Delgado L. The immune response to SARS-COV-2 and COVID-19 immunopathology-current perspectives. Pulmonology. 2021. https://doi.org/10.1016/j.pulmoe.2021.03.008.

163. Tan AT, Linster M, Tan CW, Le Bert N, Chia WN, Kunasegaran K, et al. Early induction of functional SARS-CoV-2-specific T cells associates with rapid viral clearance and mild disease in COVID-19 patients. Cell Rep. 2021;34(6):108728. https://doi.org/10.1016/j.celrep.2021.108728.

164. Thompson EA, Cascino K, Ordonez AA, Zhou W, Vaghasia A, HamacherBrady A, et al. Metabolic programs define dysfunctional immune responses in severe COVID-19 patients. Cell Rep. 2021;34(11):108863. https://doi.org/10.1016/j.celrep.2021.108863.

165. Ferastraoaru D, Hudes $G$, Jerschow E, Jariwala S, Karagic M, de Vos G, et al. Eosinophilia in asthma patients is protective against severe COVID-19 illness. J Allergy Clin Immunol Pract. 2021;9(3):1152-62. https://doi.org/10. 1016/j.jaip.2020.12.045

166. Boulanger M, Molina E, Wang K, KicklerT,XuY, Garibaldi BT. Peripheral plasma cells associated with mortality benefit in severe COVID-19: a marker of disease resolution. Am J Med. 2021;0002934321001972. https://doi.org/ 10.1016/j.amjmed.2021.01.040.

167. MysoreV, Cullere X, Settles ML, Ji X, Kattan MW, Desjardins M, et al. Protective heterologous T cell immunity in COVID-19 induced by the trivalent MMR and Tdap vaccine antigens. Med. 2021;2(9):1050-71. https://doi.org/10. 1016/..medj.2021.08.004

168. Melchor-Martínez EM, Torres Castillo NE, Macias-Garbett R, Lucero-Saucedo SL, Parra-Saldivar R, Sosa-Hernández JE. Modern world applications for nano-bio materials: tissue engineering and COVID-19. Front Bioeng Biotechnol. 2021;9:393. https://doi.org/10.3389/fbioe.2021.597958.

169. Aydin A, Cebi G, Demirtas ZE, Erkus H, Kucukay A, Ok M, et al. Combating COVID-19 with tissue engineering: a review. Emergent Materials. 2021;4(1):329-49. https://doi.org/10.1007/s42247-020-00138-6.

170. Seyfoori A, Amereh M, Dabiri SM, Askari E, Walsh T, Akbari M. The role of biomaterials and three dimensional [3D] in vitro tissue models in fighting against COVID-19. Biomaterials Sci. 2021;9(4):1217-26. https://doi.org/10. 1039/DOBM01616K.

171. Souchelnytskyi S, Nera A, Souchelnytskyi N. COVID-19 engages clinical markers for the management of cancer and cancer-relevant regulators of cell proliferation, death, migration, and immune response. Sci Rep. 2021:11(1):1-1. https://doi.org/10.1038/s41598-021-84780.

172. David A, Scott L, Jugwanth S, Gededzha M, Kahamba T, Zwane N, et al. Operational characteristics of 30 lateral flow immunoassays used to identify COVID-19 immune response. J Immunol Methods. 2021;496:113096. https://doi.org/10.1016/j.jim.2021.113096.

173. Roudbary M, Kumar S, Kumar A, Černáková L, Nikoomanesh F, Rodrigues CF. Overview on the prevalence of fungal infections, immune response, and microbiome role in COVID-19 patients. J Fungi. 2021;7(9):720. https://doi. org/10.3390/jof7090720.

174. Grifoni A, Sidney J, Vita R, Peters B, Crotty S, Weiskopf D, et al. SARS-COV-2 Human T cell Epitopes: adaptive immune response against COVID-19. Cell Host Microbe. 2021;1931312821002389. https://doi.org/10.1016/j.chom. 2021.05.010

175. Peddapalli A, Gehani M, Kalle AM, Peddapalli SR, Peter AE, Sharad S. Demystifying excess immune response in COVID-19 to reposition an orphan drug for Down-regulation of NF-kB: a systematic review. Viruses. 2021;13(3):378. https://doi.org/10.3390/v13030378.

176. Smits VA, Hernández-Carralero E, Paz-Cabrera MC, Cabrera E, HernándezReyes $Y$, Hernández-Fernaud JR, et al. The Nucleocapsid protein triggers the main humoral immune response in COVID-19 patients. Biochem Biophys Res Commun. 2021;543:45-9. https://doi.org/10.1016/j.bbrc.2021. 01.073.

177. Hussain A, Rafeeq H, Asif HM, Shabbir S, Bilal M, Mulla SI, et al. Current scenario of COVID-19 vaccinations and immune response along with antibody titer in vaccinated inhabitants of different countries. Int Immunopharmacol. 2021;108050. https://doi.org/10.1016/j.intimp.2021.108050.

178. Triggle CR, Bansal D, Ding H, Islam MM, Farag EA, Hadi HA, et al. A comprehensive review of viral characteristics, transmission, pathophysiology, immune response, and management of SARS-COV-2 and COVID-19 as a basis for controlling the pandemic. Front Immunol. 2021;12:338. https:// doi.org/10.3389/fimmu.2021.631139.

179. Salciccia S, Del Giudice F, Eisenberg ML, Mastroianni CM, De Berardinis E, Ricciuti GP, et al. Testosterone target therapy: focus on immune response, controversies and clinical implications in patients with COVID-19 infection. Therapeutic Adv Endocrinol Metab. 2021;12:20420188211010105. https:// doi.org/10.1177/20420188211010105.

180. Saad N,Moussa S.Immune response to COVID-19 infection:a double-edged sword. Immunol Med. 2021;12:1-0. https://doi.org/10.1080/25785826. 2020.1870305.

181. Kalimuddin S, Wijaya L, Chan YFZ, Wong AWL, Oh HML, Wang LF, et al. A phase II randomized study to determine the safety and immunogenicity of the novel PIKA rabies vaccine containing the PIKA adjuvant using an accelerated regimen. Vaccine. 2017;35(51):7127-32. https://doi.org/10. 1016/j.vaccine.2017.10.097.

182. Sciacchitano S, Sacconi A, De Vitis C, Blandino G, Piaggio G, Salvati V, et al. $\mathrm{H}$-Ras gene takes part to the host immune response to COVID-19. Cell Death Dis. 2021;7(1):1-3. https://doi.org/10.1038/s41420-021-00541-w.

183. Wise J. Covid-19: Rare immune response may cause clots after AstraZeneca vaccine, say researchers. 2021;373:n954. https://doi.org/10.1136/bmj.n954.

184. Almocera AE, Quiroz G, Hernandez-Vargas EA. Stability analysis in COVID-19 within-host model with immune response. Commun Nonlinear Sci Numer Simul. 2021;95:105584. https://doi.org/10.1016/j.cnsns.2020. 105584.

185. Velasco M, Galán MI, Casas ML, Pérez-Fernández E, Martínez-Ponce D, González-Piñeiro B, et al. Impact of previous COVID-19 on immune response after a single dose of BNT162b2 SARS-COV-2 vaccine. medRxiv. 2021:03.08.21253065v2. https://doi.org/10.1101/2021.03.08.21253065.

186. Quast I, Tarlinton D. B cell memory: understanding COVID-19. Immunity. 2021:1074761321000376. https://doi.org/10.1016/j.immuni.2021.01.014.

187. Chatel-Chaix L, Cortese M, Romero-Brey I, Bender S, Neufeldt CJ, FischI W, et al. Dengue virus perturbs mitochondrial morphodynamics to dampen innate immune responses. Cell Host Microbe. 2016;20(3):342-56. https:// doi.org/10.1016/j.chom.2016.07.008.

188. Mudd PA, Remy KE. Prolonged adaptive immune activation in COVID-19: implications for maintenance of long-term immunity? J Clin Invest. 2021;131(1). https://doi.org/10.1172/JCl143928.

189. Doria-Rose N, Suthar MS, Makowski M, O'Connell S, McDermott AB, Flach B, et al. Antibody persistence through 6 months after the second dose of mRNA-1273 vaccine for Covid-19. N Engl J Med. 2021;384(23):2259-61. https://doi.org/10.1056/NEJMc2103916.

190. Soffritti I, D'Accolti M, Fabbri C, Passaro A, Manfredini R, Zuliani G, et al. Oral microbiome dysbiosis is associated with symptoms severity and local immune/inflammatory response in COVID-19 patients: a cross-sectional study. Front Microbiol. 2021;12:1397. https://doi.org/10.3389/fmicb.2021. 687513.

191. Gordon DE, Hiatt J, Bouhaddou M, RezeljW, Ulferts S, Braberg H, et al. Comparative host-coronavirus protein interaction networks reveal pan-viral disease mechanisms. Science. 2020;370(6521). https://doi.org/10.1126/ science.abe9403.

192. Weinreich DM, Sivapalasingam S, Norton T, Ali S, Gao H, Bhore R, et al. REGN-COV2, a neutralizing antibody cocktail, in outpatients with Covid19. N Engl J Med. 2021;384(3):238-51. https://doi.org/10.1056/NEJMo a2035002.

193. Yang J, Wang $Q$, Zhang S, Li Z, Jiang W. Immune response of frontline medical workers providing medical support for Wuhan COVID-19 patients. China Int Immunopharmacol. 2021;94:107479. https://doi.org/10.1016/j. intimp.2021.107479.

194. da Silveira MP, da Silva Fagundes KK, Bizuti MR, StarckÉ, Rossi RC, e Silva DT. Physical exercise as a tool to help the immune system against COVID-19: an integrative review of the current literature. Clin Exp Med. 2021;21(1):15-28. https://doi.org/10.1007/s10238-020-00650-3.

195. Ciccocioppo R, Gibellini D, Astori G, Bernardi M, Bozza A, Chieregato K, et al. The immune modulatory effects of umbilical cord-derived mesenchymal stromal cells in severe COVID-19 pneumonia. Stem Cell Res Ther 2021;12[1]:1-0. https://doi.org/10.1186/s13287-021-02376-9.

196. Pasquier C, Robichon A. Computational search of hybrid human/SARSCOV-2 dsrna reveals unique viral sequences that diverge from those of other coronavirus strains. Heliyon. 2021;7(6):e07284. https://doi.org/10. 1016/j.heliyon.2021.e07284. 
197. da Silva KN, Gobatto AL, Costa-Ferro ZS, Cavalcante BR, Caria AC, de Aragão França $L S$, et al. Is there a place for mesenchymal stromal cell-based therapies in the therapeutic armamentarium against COVID-19? Stem Cell Res Ther. 2021;12(1):1-24. https://doi.org/10.1186/s13287-021-02502-7.

198. Gaebler C, Wang Z, Lorenzi JCC, Muecksch F, Finkin S, Tokuyama M, et al. Evolution of antibody immunity to SARS-CoV-2. Nature. 2021;591(7851):63944. https://doi.org/10.1038/s41586-021-03207-w.

\section{Publisher's Note}

Springer Nature remains neutral with regard to jurisdictional claims in published maps and institutional affiliations. 